\title{
Analysis of Stream-Profile Data and Inferred Tectonic Activity, \\ Eastern Ozark Mountains Region
}

\section{U.S. GEOLOGICAL SURVEY BULLETIN 1807}

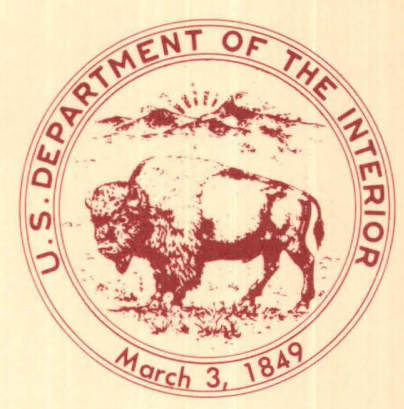





\section{Analysis of Stream-Profile Data and Inferred Tectonic Activity, Eastern Ozark Mountains Region}

BY F. A. MCKEOWN, MERIDEE JONES-CECIL, BONNY L. ASKEW, and MICHAEL B. MCGRATH

Quantitative and qualitative study of stream-profile data is used to infer recency of uplift which grossly correlates with rates of seismicity 


\title{
DEPARTMENT OF THE INTERIOR DONALD PAUL HODEL, Secretary
}

\author{
U. S. GEOLOGICAL SURVEY
}

Dallas L. Peck, Director

For sale by the

Books and Open-File Reports Section

U.S. Geological Survey

Federal Center

Box 25425

Denver, CO 80225

\section{Library of Congress Cataloging-in-Publication Data}

Analysis of stream-profile data and inferred tectonic activity, eastern Ozark Mountains region.

(U.S. Geological Survey bulletin ; 1807)

Bibliography: $p$.

Supt. of Docs. no.: I 19.3:1807

1. Valleys-Ozark Mountains Region. 2. Earthquakes-Ozark Mountains

Region. I. McKeown, F. A. (Francis Alexander), 1920- II. Series.

QE75.B9 no. 1807

[GB566.094]

$557.3 \mathrm{~s}$

87-600392

[551.2' 2'097788] 


\title{
CONTENTS
}

\author{
Abstract 1 \\ Introduction 2 \\ Regional geology and physiography 3 \\ Arkansas Valley section 4 \\ Boston Mountains section 4 \\ Salem Plateau section 5 \\ Methods of analysis 5 \\ Results of analysis 8 \\ Relationships of stream profiles, geology, and $S L$ values 8 \\ Arkansas Valley section 9 \\ Boston Mountains section 9 \\ Salem Plateau section 9 \\ Relationships of $S L$ values to lithology 12 \\ Subenvelope map 13 \\ Two-dimensional hypsometric analysis 16 \\ Stream-gradient index $(S L)$ maps 16 \\ Stream length, slope, drainage-basin area, and flow relationships 16 \\ Relationships of stream length, slope, and lithology 18 \\ Relationship of streamflow to drainage area 20 \\ Discussion and interpretation 22 \\ Possible time of uplift of the Ozarks 25 \\ Inferred rates of uplift of the Ozarks 26 \\ Relationship of inferred rates of uplift to seismicity 29 \\ Conclusions 31 \\ Acknowledgments 31 \\ References 32 \\ Appendix 34 \\ Digitizing and transformation programs 34 \\ Map-plotting programs 34 \\ Profile programs 34 \\ Analysis of the stream data 34 \\ Graytone plots 35 \\ Error analysis 35
}

PLATES

1. Map of physiographic sections, stream courses, and seismic-source zones [In pocket]

2. Profiles, stream-gradient index plots and semilog plots of streams in the Salem Plateau, Boston Mountains, and Arkansas Valley sections [In pocket] 


\section{FIGURES}

1. Index map of study area 3

2. Schematic stratigraphic section for Ozark study area 6

3. Stream profiles representative of the Arkansas Valley, Boston Mountains, and the Salem Plateau sections 10

4. Histograms showing distribution of stream-gradient indices for different lithologies or formations where differentiated 13

5. Subenvelope map derived by contouring a plot of elevation of streams at every topographic elevation along every stream course 14

6. Subenvelope map produced from a plot of elevations of streams at every topographic elevation along every stream course and smoothed by a gridding program for plotting in gray tones 15

7. Contour map of two-dimensional hypsometric values plotted midway along stream courses and calculated for the whole reach of each stream 17

8. Contour map of SL values plotted midway along stream courses and calculated for the whole reach of each stream 18

9. Stream-gradient index values calculated for reaches between every elevation contour and smoothed by a gridding program for plotting in gray tones 19

10. Regression lines for all slope- and stream-length data from Brush and the Ozark study area $\mathbf{2 1}$

11. Regression lines for slope- and stream-length data for the lithologic units of Brush and for the physiographic-lithologic sections of the Ozark study area 22

12. Cross sections showing topography, physiographic section boundaries, and Precambrian surface 28

13. Illustration of the calculation of the $S L$ and $S L^{\prime}$ values 35

14. Three cases possible if the actual stream slope is assumed to be constant and the standard error of each $20-\mathrm{ft}$ contour is $\pm 6 \mathrm{ft} 38$

\section{TABLES}

1. Regression equations and coefficients of correlation for logarithmic plots of slope and stream length of streams in the Ozark region study area and central Pennsylvania 20

2. Average flow and drainage-basin area for some streams on the Salem Plateau 23

3. Estimated rates of uplift of the Ozarks based on various estimates of relief and time of uplift 27

4. Rates of uplift along Virginia-South Carolina coast during the last 500,000 years 27

5. Rates of uplift and rates of seismicity within seismic zones in the Ozarks and the Atlantic Coast region $\mathbf{3 0}$ 


\title{
Analysis of Stream-Profile Data and Inferred Tectonic Activity, Eastern Ozark Mountains Region
}

\author{
By F. A. McKeown, Meridee Jones-Cecil, \\ Bonny L. Askew, and Michael B. McGrath
}

\section{ABSTRACT}

The enigmatic Arkansas earthquake swarm which started January 12, 1982 and located near Enola, Arkansas, was the impetus to collect and to study fluvial geomorphic data that might show regional $\left(27,600 \mathrm{~km}^{2}\right)$ crustal deformation associated with the earthquakes. Initially, study of stream profiles in the Arkansas River valley drainage within approximately $50 \mathrm{~km}$ of the epicentral area of the swarm was planned. To obtain an adequate sample of fluvial data from different geologic and physiographic environments, the study area was first extended northward to include the inferred uplift over the Newport pluton, and extended northward again to include streams flowing off the Salem Plateau.

The study area includes parts of the Salem Plateau, a very small part of the Springfield Plateau, and the Boston Mountains sections of the Ozark Plateaus Province and the Arkansas Valley section of the Ouachita Province. Rocks on which the streams flow were grouped by the predominant lithologies of each physiographic section: shale for the Arkansas Valley section, sandstone and shale for the Boston Mountains section, and limestone and dolomite for the Plateau sections. The Arkansas Valley section includes part of the Arkoma basin, the beds of which are folded into open anticlines and synclines. The the Boston Mountains section within the study area is largely a monocline on the flank of the Ozark dome. Topographically the plateau sections are a dissected plateau, but they are structurally part of the Ozark dome and contain strata that dip a few degrees to the southeast and east within the study area.

The large number (71) of streams for which profile data were collected required methods suitable for computer processing. The basic form of the data is latitude and longitude calculated from digitized $x$ and $y$ coordinates of stream courses. In addition, elevations were added to the data file where every topographic contour crossed the stream courses. Stream courses, elevation versus length profiles, and elevation versus log-length profiles were plotted from the data file. Elevations of stream courses were plotted and hand contoured to produce a subenvelope map. In addition, the following quantitative analyses were performed on the digital data: stream-gradient indices $(S L)$, first derivatives of the $S L$ calculations, two-dimensional hypsometric measurements under the stream profiles, and regression equations for slope versus length relationships.

Comparing profiles, $S L$ values and the geology for each stream indicates that streams within each physiographic section have some common attributes. In the Arkansas Valley section, the streams generally have concave upward profiles with few inflections. Streams in the Boston Mountains section characteristically have many inflections and broad convex upwards parts; $S L$ values are generally more than 100 percent higher in this section than in the Arkansas Valley section. Some inflections and broad convex reaches in the profiles where streams are crossed by faults suggested the possibility of recent faulting. Field examination of several of these faults, however, proved that the inflections and convex reaches were the result of thick-bedded units of sandstone juxtaposed against thin-bedded units of sandstone across a fault.

Profiles of streams in the Salem Plateau section are less concave upward and have fewer sharp inflections than profiles of streams in the other sections. $S L$ values of these streams are about 60 percent higher than the $S L$ values of streams in the Arkansas Valley, yet occur over a larger area of high $S L$ values than in either of the other two sections.

Histograms of $S L$ values for each major lithology show that the $S L$ values for shale and alluvium are generally lower than those for some sandstone; the $S L$ values for limestone and dolomite seem surprisingly high, but the abundance of chert in some units of limestone and dolomite may be the cause of the high $S L$ values. The highest $S L$ values are for sandstone, siltstone, and shale of the Hale Formation.

Subenvelope maps, a two-dimensional hypsometric analysis, and maps of $S L$ values show that each physiographic section has its own unique geomorphic characteristics. Lithology and geologic structure appear to control these characteristics of the Arkansas Valley and Boston Mountains sections. A large area in the Salem Plateau section has relatively high $S L$ values, and many stream profiles in this section have profiles that suggest they are not in equilibrium because of their lesser concavity. As the shape of these profiles and the $S L$ values do not appear to have any direct relationship to lithology, other possible explanations of their anomalous characteristics were examined. 
Regression equations of log slope as a function of log length were calculated for each lithology and compared with regression equations calculated for similar lithology with the same ages from a study of streams in central Pennsylvania. With one exception, the exponents of the regression equations of all six of the regression lines are in the range of -0.7 to -0.8 regardless of lithology. The exception is the exponent, -0.46 , for the regression equation for limestone and dolomite of the Salem Plateau section.

Stream-profile data for the Salem Plateau and circumstantial evidence lead us to conclude that the Ozark dome was recently uplifted and may still be in that process. Long-term average rates of uplift are calculated, and they range from 137 to $578 \mathrm{~mm}$ per thousand years. These rates are similar to the rates of uplift of the Alps and are several times greater than rates of uplift along the eastern coast of the United States.

With the exception of the very localized Arkansas earthquake swarm, nearly all of the seismicity in the study area is in the eastern part of the Salem Plateau section and is suggestive of contemporary tectonic activity. Rates of seismicity appear to qualitatively correlate with long-term uplift rates of the Ozarks and Atlantic coastal plain.

The quantitative fluvial geomorphic methods employed in the Ozark study, along with independent qualitative geologic evidence of tectonic history, appear to be a practical system for delimiting regions with tectonism that is active but too low to produce other more obvious geologic signatures.

\section{INTRODUCTION}

An enigmatic swarm of earthquakes near Enola in central Arkansas started on January 12, 1982 (Johnston, 1982), and continued for more than 3 years with bursts of increased activity every few months. No apparent geologic or geophysical characteristics were identified with this activity. The study reported here was begun as an attempt to identify geomorphic evidence of geologically young local or regional deformation that may have been associated with the activity. Although the lack of a plausible explanation of the Arkansas earthquake swarm was the impetus for this study, the methods used and large area over which they were applied led to a much more comprehensive and complex study than planned.

Because no causative local features had been identified to explain the Arkansas earthquake swarm, it was thought that examination of regional crustal deformation could prove useful. It is well known that the regions of the world with the highest rates of seismicity, such as the Aleutian arc, the San Andreas fault zone, and the Himalayan Mountains also have high rates of deformation. The rates of deformation and seismicity in the central United States are very low, but it is reasonable to expect a correlation between them. Logic indicates that strain released by an earthquake may have built up over tens to thousands of years, particularly in areas of low seismicity. Such long-term tectonic strain is probably distributed through a large volume of rock and affects a large surface area.

Semiquantitative geomorphic methods seemed the most feasible approach for identifying regional crustal deformation and have been used successfully in other areas. Flint (1941), for example, reasoned from a study of terraces and topographic profiles that the Mississippi River between St. Louis, Mo., and Cairo, Ill., is antecedent to uplift of the Ozark dome in post-Tertiary prePleistocene time. Hack (1973b, 1982) interpreted tectonic movement along the Blue Ridge front from a study of stream gradient indices and other geomorphic parameters. Russ (1982) delimited the Lake County uplift in the New Madrid, Mo., area by geomorphic analysis. Earlier, Shulits (1941) recognized that the profile of the Mississippi River has an anomalously low gradient where it crosses the Lake County uplift but did not pursue this observation as it was incidental to the main topic of his paper. Mayer and Wentworth (1983) inferred movement on the Stafford fault by statistical analyses of streamgradient indices. Recent papers by Burnett and Schumm (1983) and by Schumm and others (1982), who used studies of downvalley and river profiles, have interpretations of neotectonic movement associated with the Wiggins and Monroe uplifts in Louisiana and Mississippi. Several of the same methods used in this study of the eastern Ozark Mountains were applied on a very small scale by Keller (1977), Keller and Rockwell (1984), and Michele Miller (written commun., 1983) to identify "tectonic cells" in parts of California and by Seeber and Gornitz (1983) to identify crustal deformation associated with seismicity in the Himalayan Mountains.

Identification of crustal deformation associated with contemporary earthquakes is directly related to the older problem of explaining the present high elevations of old rocks in many mountain ranges. Studies of denudation rates and isostatic uplift (Schumm, 1963a; Judson and Ritter, 1964; Ahnert, 1970; Young, 1982) show that rates of uplift must vary greatly over long periods of time. For example, Hack (1982), using Ahnert's work, estimated that the Appalachians should have had a relief of $30,000 \mathrm{~m}$ in Paleocene time if no uplift other than isostatic uplift had occurred during the interval between the Paleocene and present. Using the same rates of denudation and uplift, the Salem Plateau of the Ozark Mountains would have had a relief of about $25,000 \mathrm{~m}$ in Paleocene time. Both estimates, of course, are unrealistically high. They do indicate, however, that because no evidence is known of tens of thousands of meters of rock of late Paleozoic age overlying the currently exposed Paleozoic rocks in the Appalachians and Ozarks, considerable uplift must have occurred in these regions since early Tertiary time.

Initially, an analysis of stream profiles within approximately $50 \mathrm{~km}$ of the epicentral area of the Arkansas 
earthquake swarm in the Arkansas Valley physiographic section was planned. Because Glick (1982) had interpreted post-early-Paleocene uplift in the vicinity of the Boston Mountains physiographic section over the Newport pluton about $100 \mathrm{~km}$ northeast of the epicentral area, additional stream profiles in this section and the southern part of the Salem Plateau section were added in an attempt to identify the uplift by stream-profile analysis. To obtain an adequate sample of stream profiles for comparison with the Boston Mountains section, the study area was again extended as far north as $37.00^{\circ}$. The resulting area covered in this study is about $27,600 \mathrm{~km}^{2}$.

\section{REGIONAL GEOLOGY AND PHYSIOGRAPHY}

Many geologic factors must be considered in any study whose principal objective is to identify large (thousands of square kilometers) regions that may have been uplifted or have subsided. As this study employs qualitative and quantitative parameters of stream profiles, it is necessary to consider the principal factors that may affect the profiles in detail commensurate with the size of the streams and the size of the region being studied. The principal geologic factors are lithology and structure over which the streams flow. In addition, differences in the physiography of the region must be considered because of the effect of relief on rates of erosion. These factors are summarized briefly in this section and considered in more detail in subsequent sections.

The Ozark study area includes parts of two physiographic provinces, as defined by Fenneman (1938), the Ozark Plateaus and the Ouachita province (pl. 1). The northern part of the area is in the Salem and Springfield Plateau sections of the Ozark Plateaus, the middle part is in the Boston Mountains section of the Ozark Plateaus, and the southern part is in the Arkansas Valley section of the Ouachita Province (fig. 1). The sections of the

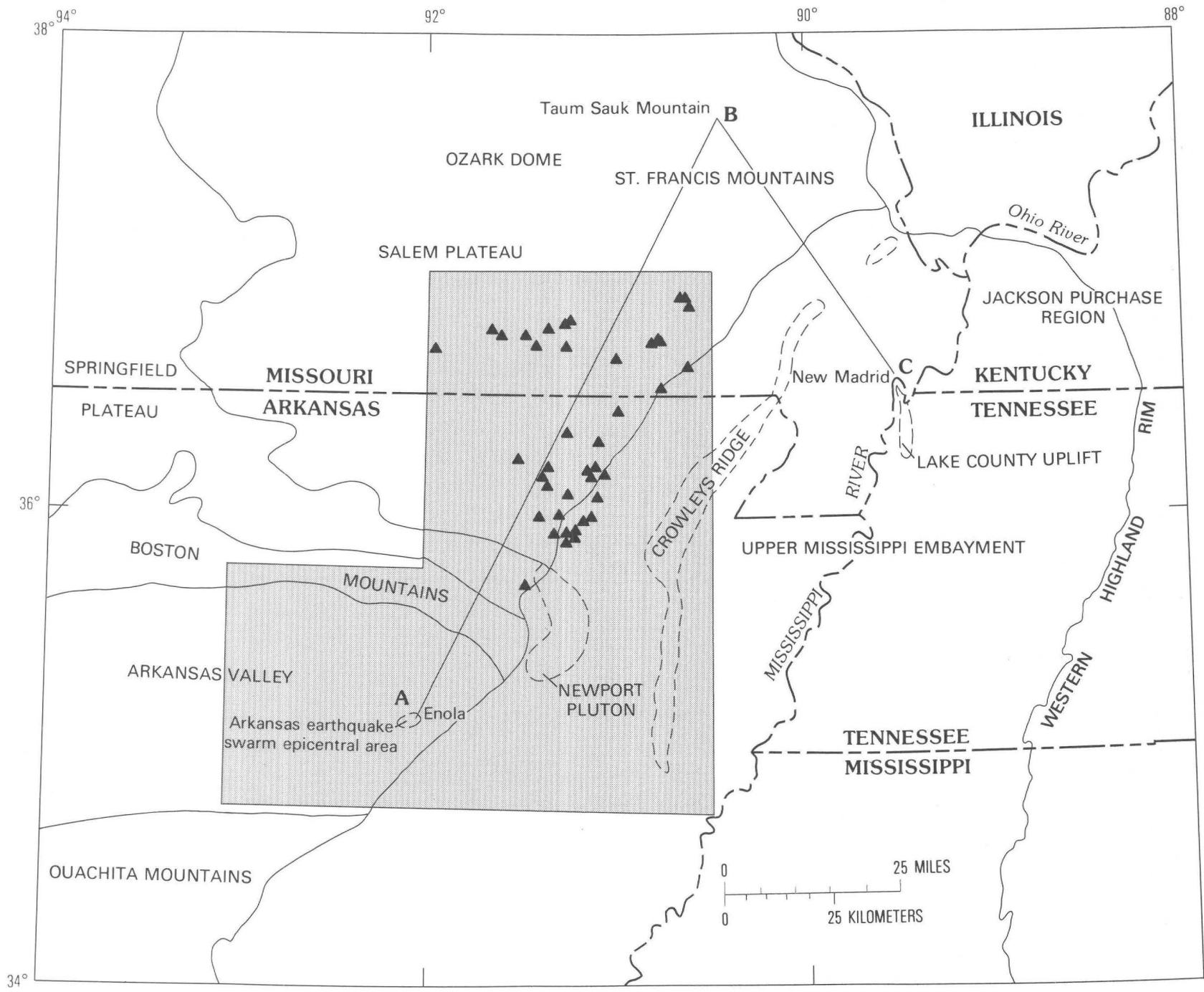

Figure 1. Index map of study area (shaded), generalized physiographic section boundaries, lines of cross sections A-B and $\mathrm{B}-\mathrm{C}$, places mentioned in text, and epicenters (triangles) within study area of magnitude 2 or greater earthquakes from July 1974 through June 1984 (Robert Herrmann, written commun., 1984). 
Ozark Plateaus are largely delimited by Fenneman (1938) on the basis of the age of the underlying rocks. The Salem Plateau is underlain by Ordovician and older rocks, the Springfield Plateau is underlain by rocks of Mississippian age, and the Boston Mountains are a dissected plateau underlain by rocks of Pennsylvanian age. The Arkansas Valley section of the Ouachita province is also underlain by Pennsylvanian rock but is delimited mostly on the basis of structure. It consists of moderately folded Pennsylvanian rocks between the tightly folded and faulted rocks of the Ouachita Mountains to the south and the gently to moderately dipping rocks of the Ozark Plateaus to the north. The boundaries between the sections shown on figure 1 are generalized from the contacts of Ordovician, Mississippian, and Pennsylvanian rocks on the Geologic Map of Arkansas (Haley and others, 1976). In general, the boundaries are close to the courses of the White and Little Red Rivers.

The geology and physiography differ from section to section. Streams in the study area, therefore, flow over a wide range of rock types and structures, both of which partly control the physiography. Except for thin deposits of Quaternary alluvium in some stream valleys, nearly all of the study area is underlain by Cambrian to Pennsylvanian rocks. Rock units shown in the stratigraphic section (fig. 2), were grouped into three predominant lithologies: shale, sandstone-shale, and limestone-dolomite. These lithologies coincide approximately with the physiographic sections of the study area and this coincidence is the basis for dividing the area into three parts. These parts will be referred to by their physiographic designation-Salem Plateau section, Boston Mountains section, and Arkansas Valley section-in the following text.

The streams studied in each section are listed below. An additional identifier is used to specify a stream whose name occurs more than once. For example, four Big Creeks were digitized. These are designated on plate 1 and on the lists below as S Big, Big S, N Big, and NN Big. Explanation is also needed for streams shown on plate 1 but which are not listed below. All streams on plate 1 were digitized, but some were not used in the analyses and are not listed below because they were not within one of the three physiographic sections (for example, Wattensaw Bayou) or their entire length was not within the study area (for example, Arkansas River, Black River, Meto Bayou, and White River).

Streams in the Arkansas Valley Section

Batesville Creek
Big S Creek
Black Fork Creek
Bridge Creek
Bull Creek
Cadron Creek
Cane Creek
Clear Creek
Cove Creek

$$
\begin{aligned}
& \text { Hackers Creek } \\
& \text { Jacks Fork Creek } \\
& \text { Kuhn Bayou } \\
& \text { Little Cypress (08) Creek } \\
& \text { Little Cypress (11) Creek } \\
& \text { Little Creek } \\
& \text { Little Red River } \\
& \text { Little Maumelle River } \\
& \text { Magness Creek }
\end{aligned}
$$

Cypress Bayou
Cypress Creek
DesArc Bayou
East Cadron Creek
East Fork Remove Creek
Fourmile Creek
Greenbriar (2) Creek

Streams in the Boston Mountains Section
Muddy Bayou

North Cadron Creek

Warren Creek

White Oak (08) Creek

White Oak (11) Bayou

West Fork Remove Creek
Mill (2) Creek

$$
\begin{aligned}
& \text { Departee Creek } \\
& \text { Fourteenmile Creek } \\
& \text { Glaise Creek } \\
& \text { Greenbriar Creek } \\
& \text { Mill (h) Creek } \\
& \text { N Big Creek } \\
& \text { Salado Creek } \\
& \text { Tenmile Creek } \\
& \text { Wagon Wheel Creek }
\end{aligned}
$$

Streams in the Salem Plateau Section

\author{
Myatt Creek \\ N Spring Creek \\ NN Big Creek \\ Piney Fork Creek \\ Polk Bayou \\ Reeds Creek \\ South Fork Spring River \\ S Big Creek \\ Spring Creek \\ Spring River \\ Strawberry River \\ Sullivan Creek
}

\section{Arkansas Valley Section}

This section (fig. 1) is largely underlain by shale and sandstone of Pennsylvanian age. The beds are folded into open anticlines and synclines and are part of the Arkoma basin. Erosion of the folded rocks has produced a landscape characterized by broad, shale synclinal valleys rimmed with moderately dipping sandstone. Though sandstone units are generally less than $10 \mathrm{~m}$ thick, their resistance to erosion relative to the shale makes them ridge formers.

The elevation of streambeds in this section ranges from approximately 80 to about $220 \mathrm{~m}$. Maximum elevations of the interfluves are a few tens of meters higher. Of the three sections in the study area, the Arkansas Valley section is the most highly dissected, has the lowest streamgradient index values, and has the least amount of upland area.

\section{Boston Mountains Section}

The Boston Mountains section (fig. 1) is the smallest of the three study areas. It is underlain largely by 
Pennsylvanian sandstone and shale and Mississippian limestone and sandstone. The Boston Mountains have been described as a dissected plateau (Purdue, 1901), implying flat-lying rocks, and west of the study area this description is generally correct. Within the study area, however, the rocks are folded into a monocline on the south flank of the Ozark dome. Erosion of the monocline has produced a prominent cuesta known as the Boston Mountain escarpment. Bretz $(1965$, p. 13) believed that the escarpment " $* * *$ is the retreating cuesta of a probably once-complete, Pennsylvanian cover of the entire [Ozark] dome, except for the St. Francois Mountains." The White River flows between this escarpment and the Salem Plateau to the north.

The elevation of the streambeds ranges from approximately 80 to $260 \mathrm{~m}$. Maximum elevations of the interfluves are as much as $100 \mathrm{~m}$ higher. Maximum values of stream-gradient indices are highest in this section, but high values are not as numerous as in the Salem Plateau. Similarly, though elevations are highest, the relative amount of upland area is not as great in the Boston Mountains as in the Salem Plateau.

\section{Salem Plateau Section}

The largest part of the study area is in the Salem Plateau section (fig. 1) which, as stated earlier, includes a small part of the Springfield Plateau. It has the most uniform rock types, structures, and topography of the three sections. Ordovician and Mississippian limestone and dolomite, some of which contain considerable chert, are the predominant rock types. The St. Peter Sandstone and the Roubidoux Formation of Ordovician age also underlie part of the section. Topographically the province appears to be a plateau; however, the province is structurally part of the Ozark dome. Within the study area dips of bedding are a few degrees to the southeast and east away from the apex of the dome which is located only a few tens of kilometers north of the study area. Elevations of streambeds range from approximately 80 to $260 \mathrm{~m}$; maximum elevations between streams range from a few tens to hundreds of meters higher.

\section{METHODS OF ANALYSIS}

Because the primary objective of this investigation was to detect crustal strain within a large $\left(\sim 27,600 \mathrm{~km}^{2}\right)$ region, methods of investigation that permitted rapid acquisition of large amounts of data suitable for computer processing were needed. This was achieved by compiling a large digital database utilizing a VAX $-780^{1}$ mainframe and associated peripheral equipment. The basic form of the data used in the study was latitude and longitude points defining stream courses for 71 streams whose lengths were generally greater than $10 \mathrm{~km}$. In addition, elevations were entered for each point in the data file where an elevation contour crossed the stream course. These data were derived from $x, y$, and $z$ coordinates entered from a Summagraphics ${ }^{1}$ digitizer using the program "DIGTIZ" written by Askew. The $x$ and $y$ coordinates were then transformed into latitude and longitude using a Lambert Equal Area projection in another program "MAPTRN" also written by Askew.

Altogether, streams from 153 71/2-minute quadrangles and from six 15-minute quadrangles were digitized. Using programs written by Bonny Askew and M. McGrath, the data were plotted as stream courses, as profiles of elevation versus length, and elevation versus log-length . Elevation of stream courses was plotted and hand contoured to produce a subenvelope map (Stearns, 1967). In addition, using programs written by M. JonesCecil, the following quantitative analyses were performed on the digital data: calculation of stream-gradient indices $(S L)$, first derivatives of the $S L$ calculations (second derivatives), two-dimensional hypsometric measurements under the profile curves, and regression equations for slope-length relationships. Results of the calculations, except for those for the second derivatives, are described in more detail under "Results of Analysis". Brief descriptions of the computer programs used for digitizing, plotting, and numerical analyses as well as a discussion of the sources and magnitudes of errors are given in the appendix. It is important that the reader be aware of the possible large error in the value of contours of elevation, as discussed in the appendix. In essence, inflections in stream profile, changes in the $S L$, or slope values involving only one or two contours may be the result of inaccurate values. Field checking the location, elevation, and geology of every inflection is the only way to determine their cause.

None of the methods and analyses used in this report are new, but some may not be known to many readers unfamiliar with literature on fluvial geomorphology. Therefore, it seems appropriate to summarize some of the relationships among fluvial hydraulic parameters and their derivations, as used or referred to in this report. The reader is especially cautioned to become aware of the dimensional inequalities which are commonly incorporated into a constant, that most relationships are derived empirically from $\ln$-ln plots, and not to confuse slope with stream-gradient index. For more detailed explanations of the relationships see Hack (1957, 1973a), Leopold and others (1964), Morisawa (1968), and Richards (1982). In the equations given below $S=$ slope, $L=$ length along channel of stream from source,

\footnotetext{
${ }^{1}$ Any use of trade names is for descriptive purposes only and does not imply endorsement by the U.S. Geological Survey.
} 


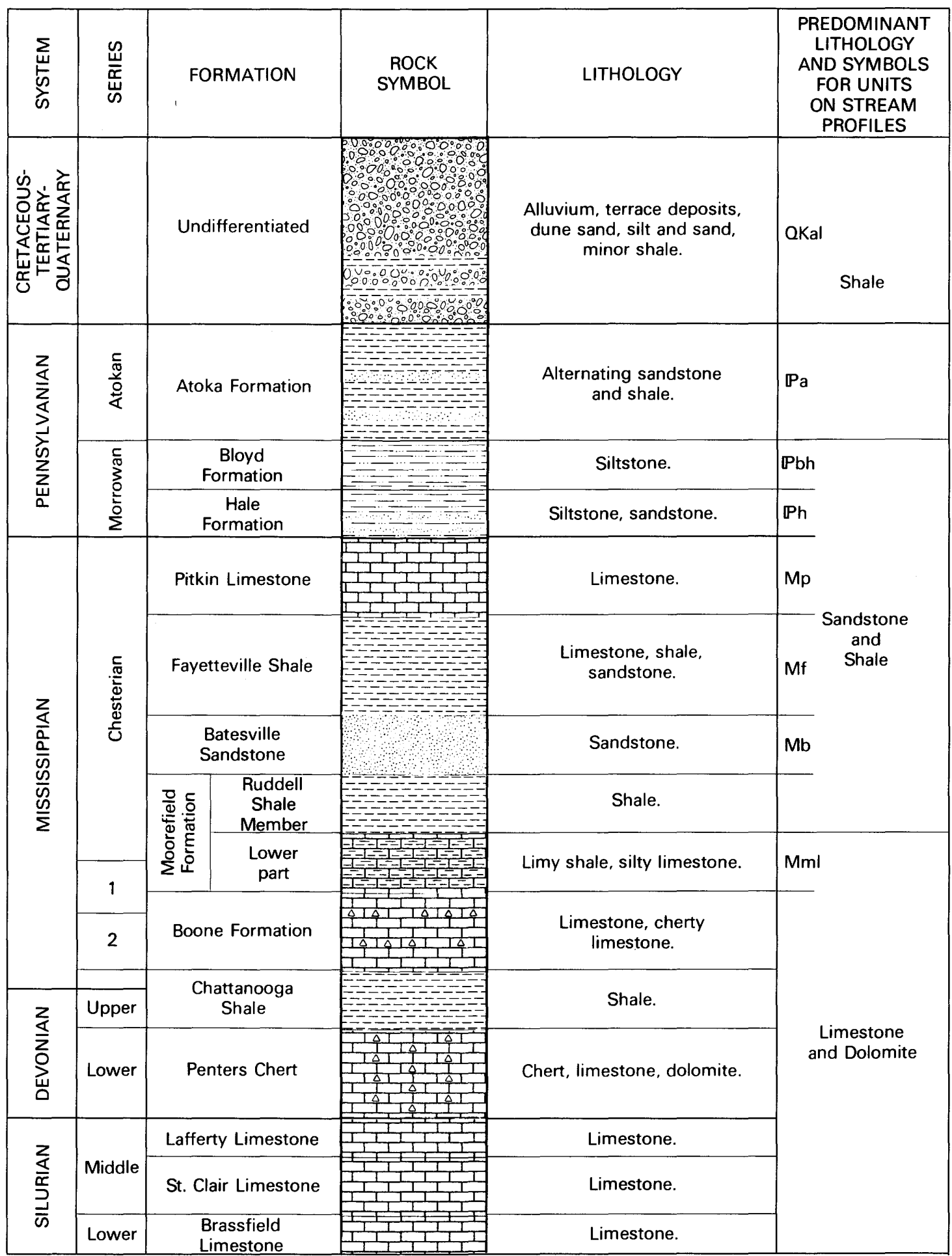

Figure 2 (above and facing page). Schematic stratigraphic section of rocks in the study area. Data are generalized from Caplan (1954), Frezon and Glick (1959), and B.R. Haley and E.E. Glick (written commun., 1983).

$H=$ elevation at a point along a stream, $A=$ drainage area, $Q=$ discharge and $M=$ median particle size in millimeters.

Stream-gradient index $(S L)$ is an important parameter because, in essence, slope is normalized to length and provides a basis for comparing slopes of reaches of streams of different sizes. It was derived by Hack (1957) when he noted that stream profiles plotted as semilogarithmic graphs tended to be straight lines or a series of straight-line segments. The equation for such a line is 


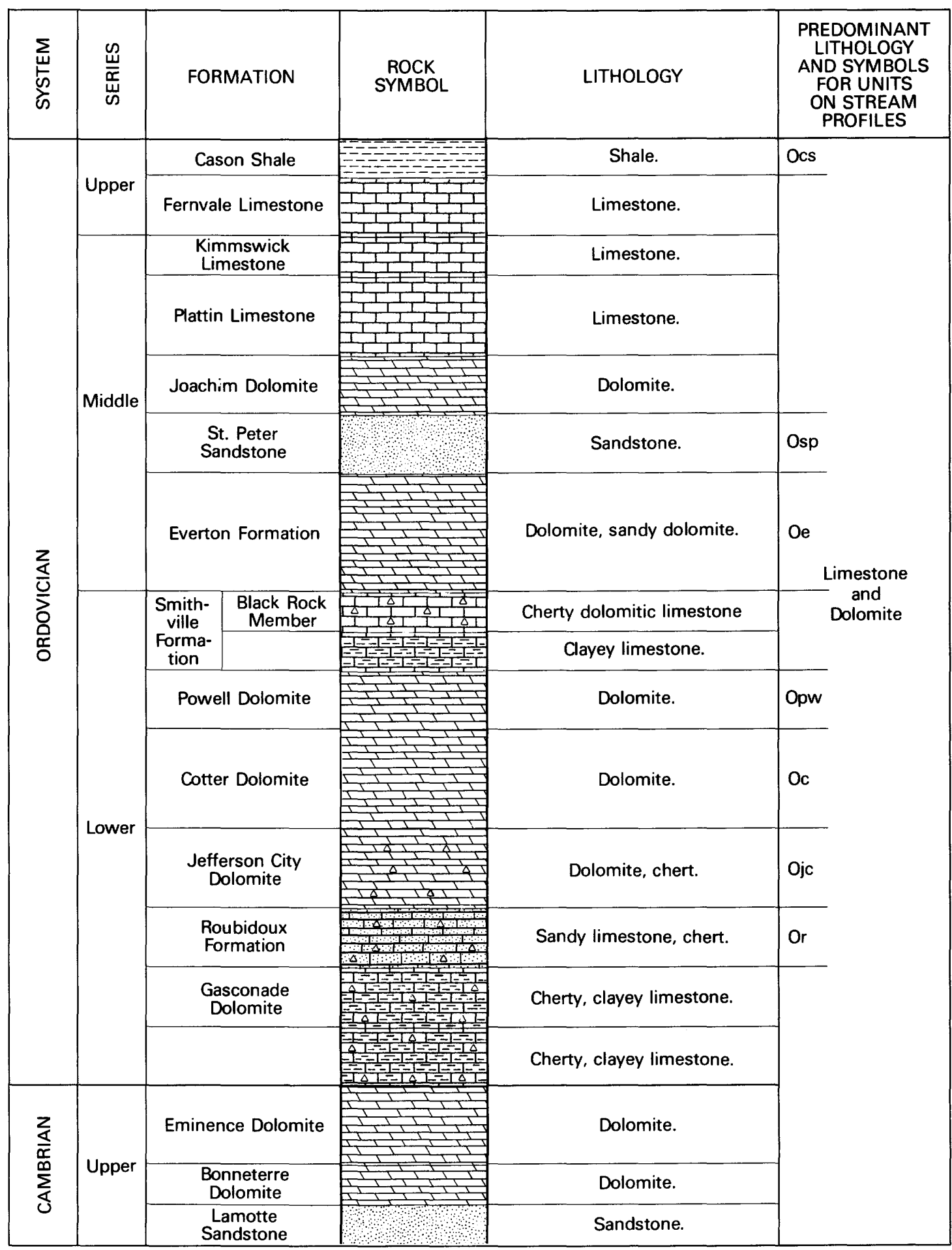

$$
H=C-k \ln L
$$

where $C$ and $k$ are constants and the slope at a point on the line is

$$
\begin{aligned}
\frac{d H}{d L}= & k L^{-1} \text { or } S=k L^{-1} \text { and } \\
& S L=k \text { (stream-gradient index) }
\end{aligned}
$$

$k$, however, is the slope of the semilogarithmic profile which is

$$
\frac{\Delta H}{\Delta \ln L}=k=S L \text {. }
$$

In addition to the value of $S L$ for comparing slopes of any size of reach, $S L$ is crudely related to competence 
of a stream. Hack (1957) derived empirically the following equation:

$$
S \propto\left(\frac{M}{A}\right)^{0.6}
$$

Also, he and others (for example, Leopold and others, 1964) have shown in general that

$$
L \propto A^{0.6} .
$$

This relationship is commonly known as Hack's law (for example, Shimano, 1975), though the exponent on $A$ may be dependent on the shape or size of the drainage basin (Mosley and Parker, 1973). Substitution of equation 5 into equation 4 gives

$$
S \propto \frac{M^{0.6}}{L} \text { or } S L \propto M^{0.6} .
$$

Two other commonly used and important relationships derived empirically (Leopold and others, 1964) are

$$
Q \propto A^{0.75},
$$

for bankfull discharge, and

$$
S Q=\text { constant, }
$$

when power is equally distributed along a stream.

The above relationships are pertinent to parts of this report but are only a small sample of many relationships of fluvial hydraulic parameters derived both empirically and theoretically primarily since Horton (1945) first showed how a number of parameters of a stream system are interrelated.

\section{RESULTS OF ANALYSIS}

When this study was started, the kind of analysis most useful for detecting regional, geologically young deformation, should it be present in the landscape, was not known. The study, therefore, was an experiment, not an application of methods known to provide definitive results. Initially, we anticipated that Hack's stream-gradient indices would be most useful for a synoptic analysis of streams to identify gross regional differences. However, because there is no single, proven quantitative method which solves our particular problem, other methods and parameters were examined as well. Some methods of analysis proved to be more useful than others. This section contains descriptions of the results of each type of analysis, including those that were not particularly useful, in order to document and compare different methods.

\section{Relationships of Stream Profiles, Geology and $S L$ Values}

The simplest analysis made was an examination of plots of stream profiles plotted in Cartesian coordinates. These stream profiles, also called long profiles in some literature, will simply be referred to herein as profiles. Semilog profiles were also examined, because they show changes in slope without the ubiquitous decrease in slope with distance downstream observed on all profiles; that is, they essentially normalize slopes to distance. Plots of stream-gradient indices versus distance are also presented in this section as another way of examining the semilog profiles.

Streams tend to have slopes adjusted so that erosion and deposition are balanced; such streams are considered graded. If such an adjustment is attained, and the stream maintains the same profile for a long period of time, the stream is said to be in equilibrium. An extensive literature exists discussing what factors interact to produce equilibrium, whether equilibrium is ever achieved, and how best to define it (see, for example, Mackin, 1948; Leopold and others, 1964; Richards, 1982). Profiles are generally concave upward, rarely convex upward. The semilog plots of height versus log length tend to be straight lines or a series of straight-line segments. Several explanations have been suggested for the shape of profiles and include both physical and stochastic processes. Shulits (1941), for example, derived an exponential equation for profiles from Sternberg's law of abrasion. Leopold and Langbein (1962) also derived an exponential equation, but from a random walk model. Whatever the explanation may be for the shape of profiles, there is general agreement that streams that are approximately graded have a concave upward profile which may be described by an exponential equation.

Profiles of representive streams with geologic annotations, corresponding semilog plots, and plots of $S L$ values versus length are discussed below. These samples are plotted at scales large enough to accommodate the annotations on them (pl. 2). The same samples are all plotted at the same scale (figs. $3 A, 3 B$, and $3 C$ ) so that a direct comparison of their slopes and shapes can be made. The streams chosen by the authors are intended to represent the most distinctive characteristics of profiles for each province. Nevertheless, the choice must be considered a subjective judgment. The reader is cautioned not to attempt rigorous interpretation of the uppermost part of the stream data, because streams close to drainage divides are very likely to be much more out of equilibrium than lower reaches of the stream. Hack (1973a, p. 427) has noted that the upper reaches of a stream within about $0.5 \mathrm{mi}(0.8 \mathrm{~km})$ of a drainage divide “*** is not sculptured primarily by the kinetic energy of flowing water.' This study of 66 profiles, semilog plots, and $S L$ 
plots suggests that a stream may not be approaching a balance between erosion and deposition for as much as $5 \mathrm{~km}$ from its source.

\section{Arkansas Valley Section}

Profiles of streams in this section have a wide range in concavity and have only minor inflections (pl. 2). In general, the profiles are more concave than profiles of streams on the Salem Plateau and have fewer pronounced inflections than profiles of streams in the Boston Mountains. The streams in this province flow on shale and sandstone of the Atoka Formation. Shale is the predominant lithology, but the sandstone units, which are generally less than $10 \mathrm{~m}$ thick, cause local sharp changes in slope. In some places, however, stream profiles and $S L$ values do not appear to be dependent on lithology. Examples of profiles and $S L$ values for streams flowing largely on shale and alluvium are Bull, Cane, and Cove Creeks (pl. 2); their profiles are generally concave with few inflections. An example of the influence of a thin resistant sandstone unit is the inflection in the Cove Creek profile about $8 \mathrm{~km}$ from the headwaters (pl. 2). East Fork Remove Creek (pl. 2) is an example of the apparent lack of any large effects on the profile and $S L$ values by lithology. The profile and $S L$ plot change most markedly where the creek flows on alluvium. Causes for the slightly convex parts of the profiles are not known. More than 85 percent of the $S L$ values for each of these streams are less than 75 .

Cypress and Cadron Creeks (pl. 2) are examples of streams with pronounced inflections. The profile of Muddy Bayou (pl. 2) is similar to that of Cadron and Cypress Creeks and has no unusual characteristics even though it flows through the epicentral area of the Arkansas earthquake swarm. For comparison, note that less than 75 percent of the $S L$ values for each of the two streams are less than 75 .

\section{Boston Mountains Section}

Streams in this section flow predominantly on calcareous sandstone, siltstone, and shale of the Hale Formation of Pennsylvanian age. Some of the sandstone units are thick bedded, which, as described below, is a much more important factor affecting slope than is overall lithology. The geologically annotated profiles indicate that the streambeds are nearly monolithologic. The profiles are characterized by many inflections and broad convex upward parts (pl. 2). $S L$ values are much higher than $S L$ values of streams in the Arkansas Valley section.

Two of the most striking aspects of profiles for this section are a coincidence of inflections in the profiles with the location of faults and a rather large number of broad convex upward reaches. The coincidence of inflections with faults in the profile for Salado Creek in particular (pl. 2) suggested that some of the faults may be geologically young. However, field investigations of parts of Salado, as well as Tenmile and Fourteenmile Creeks (pl. 2), showed that the inflections in the profiles are related to the size of rocks in the streambed. The coincidence of inflections with faults is not related to fault scarps but is the result of the juxtaposition of thick-bedded units against thin-bedded units across a fault. No evidence of fault scarps was found. Much of the rock in the streambed is from thin-bedded sandstone and siltstone from the Hale Formation. Locally, however, the streams cut into thick-bedded sandstone. The thin-bedded rocks break into pebbles and cobbles from a few to several tens of centimeters across and a few centimeters thick. The thickbedded sandstone commonly breaks into rectangular boulders as much as 1-2 $\mathrm{m}$ across. Where these boulders armor the streambed, the slope of the stream is increased downstream, but upstream for a short distance the slope is decreased, resulting in a convex stream profile.

Streams in the Boston Mountains section have a large range of $S L$ values and have a high proportion of $S L$ values greater than 150 . It is possible that lithology and geologic structure are the cause of the overall high values, although a tectonic component cannot be precluded. Although the Hale Formation, on which streams in the section flow, comprises sandstone, siltstone, and shale, it is monolithic in the sense that the two most common lithologies, sandstone and siltstone, are both very resistant to erosion. And judging from profiles and $S L$ values, even the shale in the Hale Formation is quite resistant (pl. 2, Salado Creek). Geologic structure may also contribute to the high $S L$ values and character of the profiles, because most of the streams are flowing down the dip slope or off of the escarpment of the Boston Mountains. Thus, the slope and $S L$ values of the streams may be determined in part by the dip of beds or by the relatively steep north slope of the Boston Mountains escarpment.

\section{Salem Plateau Section}

Streams in this section flow predominantly on Ordovician and Mississippian limestone and dolomite; locally St. Peter Sandstone underlies the streams (pl. 2). In addition, much of the upper part of Eleven Point River (not illustrated) is in the Roubidoux Formation. In general, the profiles of the Salem Plateau section are not as concave nor do they have as many sharp inflections as profiles of the other two sections. The less concave shape of the profiles in this section was, on first interpretation, thought to be due to lithology or by decreased surface flow from diversion of runoff to underground flow through sinkholes. Several observations do not support these notions. 

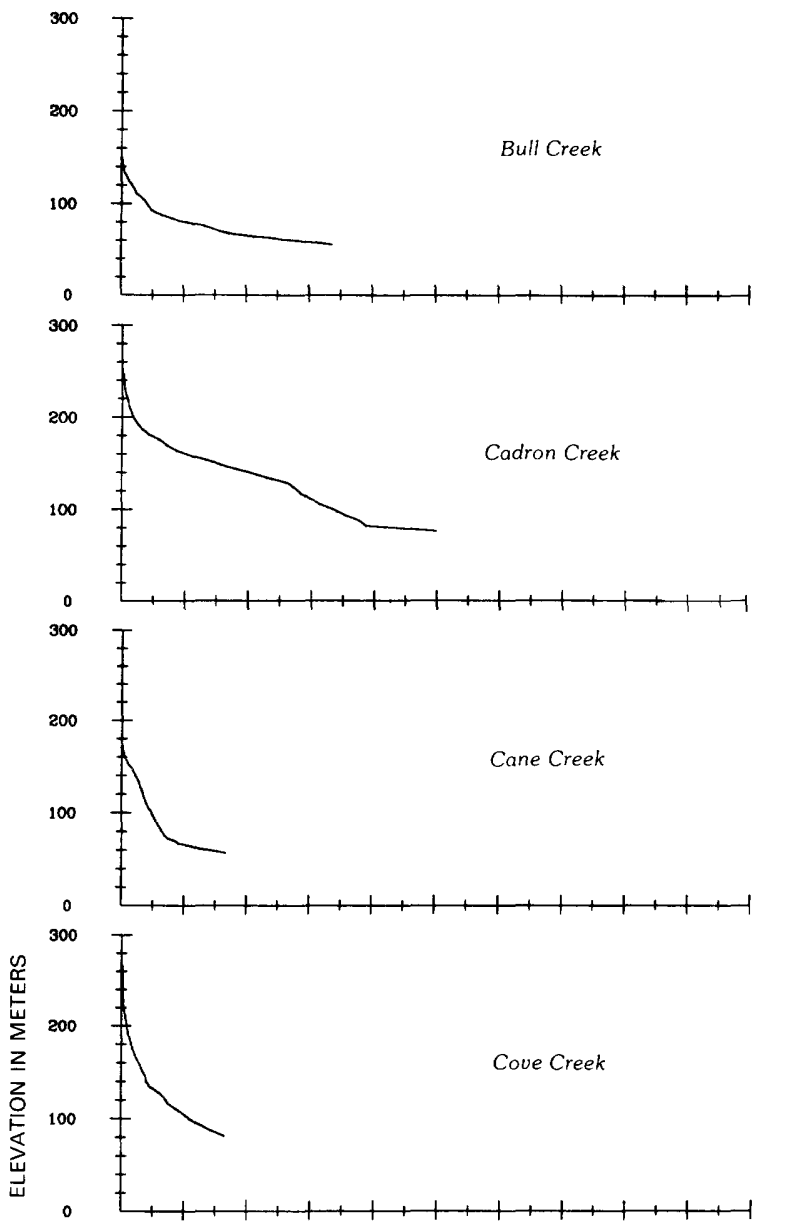

300

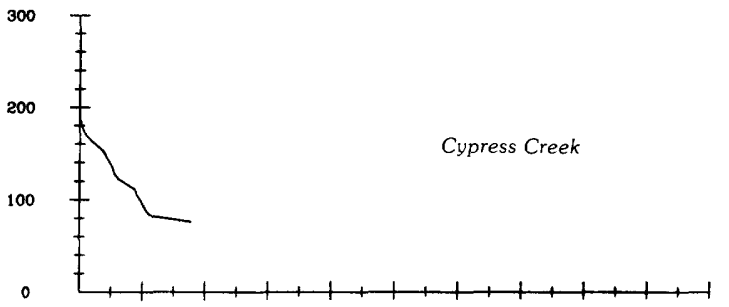

300
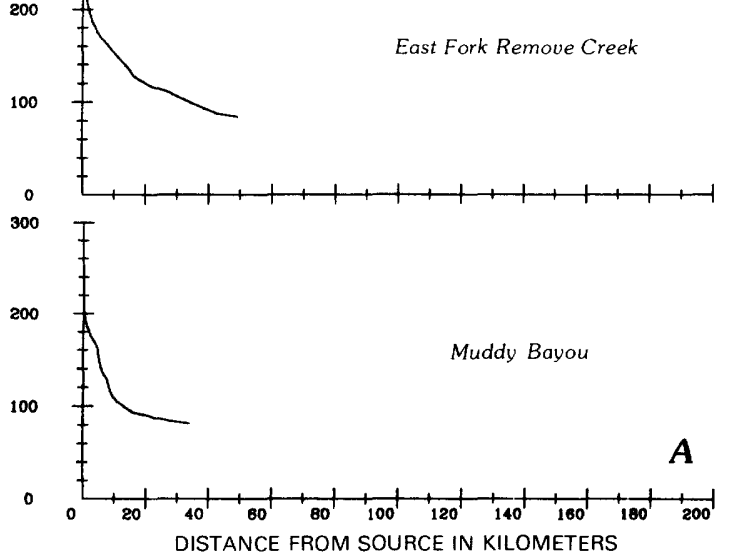
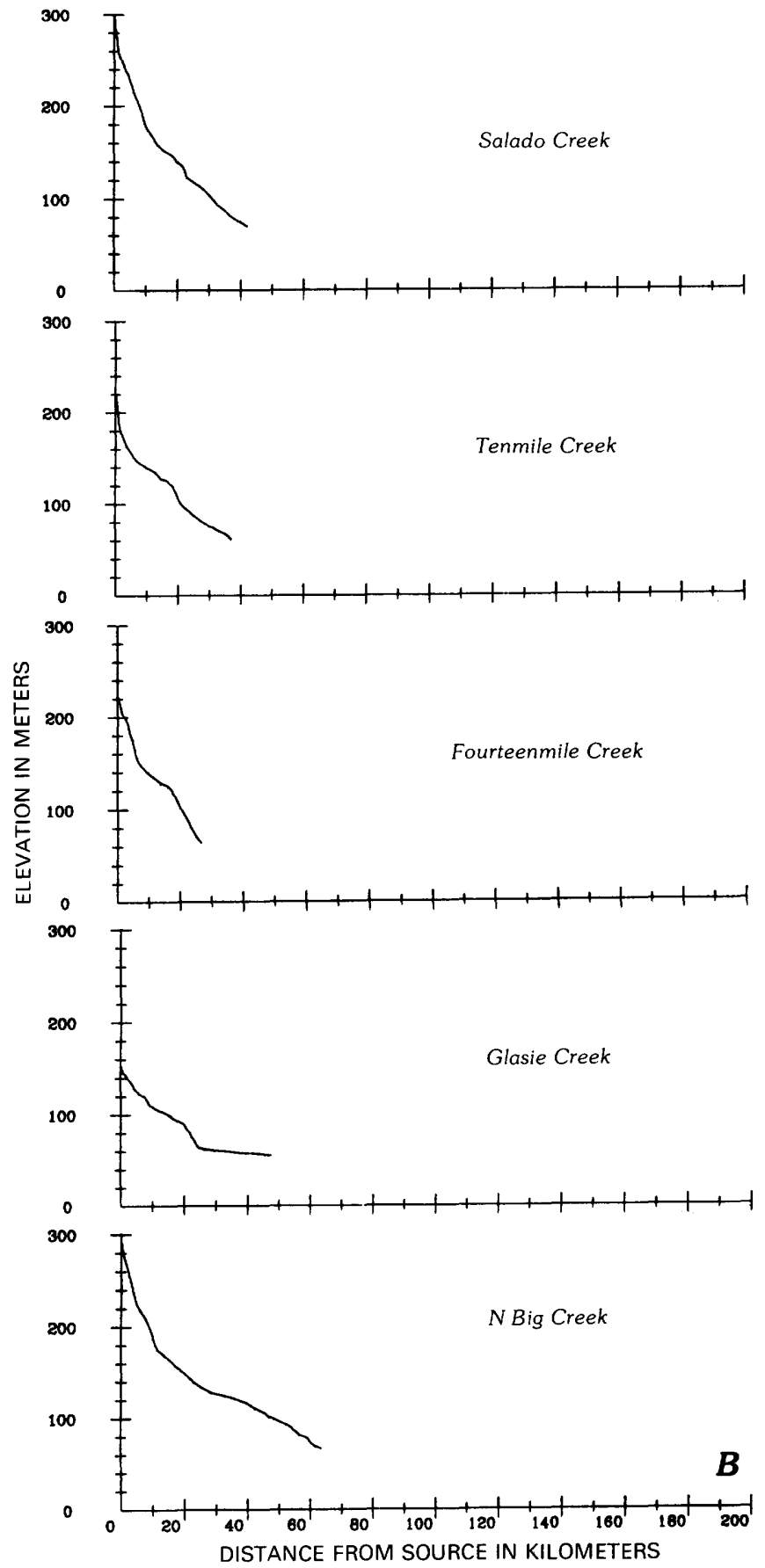

Figure 3 (above and facing page). Stream profiles (plotted at the same scale) that are representative of $A$, Arkansas Valley section; $B$, Boston Mountains section; and $C$, Salem Plateau section. 


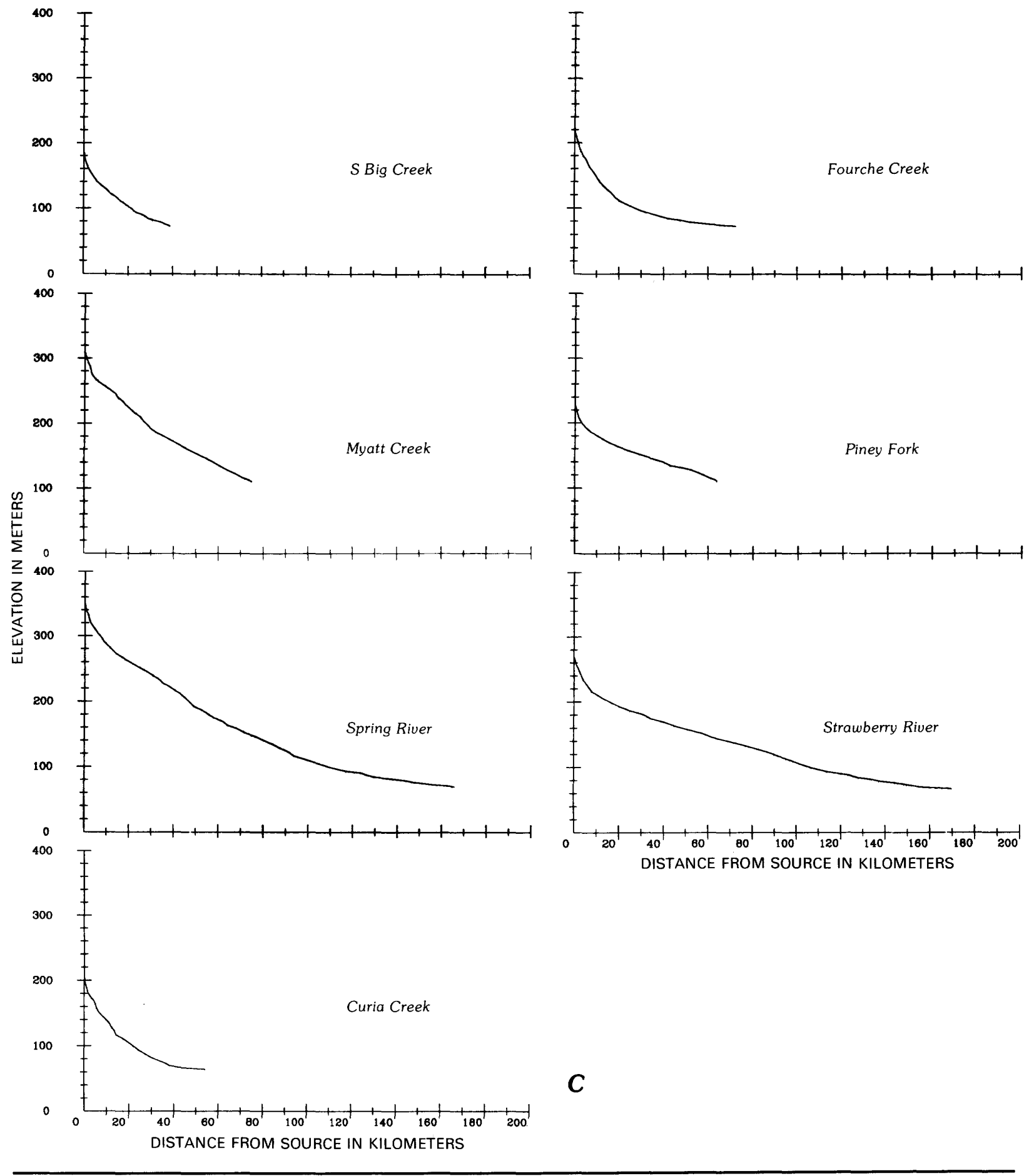

On closer examination, the effect of lithology on profile shape appears to be small or negligible. For example, S Big Creek (pl. 2) flows entirely on sandstone and sandy dolomite of the Everton Formation, and Myatt Creek (pl. 2) flows on dolomite of the Cotter and Jefferson City Dolomites. Profiles of each of these creeks have small inflections and convex parts, but their general shapes are similar even though the rocks on which they flow are dissimilar. Comparison of lithology with profile shape and with $S L$ values from profiles flowing on different carbonate rocks and sandstone does not show any strong correlation. On a broader scale, the same lack of correlation between $S L$ values and lithology is seen and is discussed in the section on relationships of $S L$ to lithology. An exception to this generalization is the profile of Piney Fork Creek (pl. 2). About $52 \mathrm{~km}$ from its source, the slope increases abruptly. Upstream of this location the stream flows mostly on nonresistant clayey 
Powell Dolomite. Below $52 \mathrm{~km}$, the creek flows on the Everton Formation which has beds of resistant sandstone. Also, E. E. Glick (written commun., 1983) notes that several meander cutoffs occur downstream. Both of these factors could explain the increase in slope of the stream. Another lithologic factor initially considered to be of importance was bed load. The streambeds in the Cotter Dolomite, the Jefferson City Dolomite, and the Roubidoux Formation are armored with chert fragments. The fragments ranged from less than 1 to about $20 \mathrm{~cm}$ in cross section. At low flow, fragments more than a few centimeters across appeared to be stationary in the streambeds, and, therefore, do act as an armor, inhibiting erosion of the underlying rock. However, gravel beds of chert 1-2 $\mathrm{m}$ above low-water stage attest to a large amount of transport during flood stages, thereby allowing for erosion of the underlying rock. As most erosion occurs during floods, the effect of the chert bed load on erosion of a channel is probably minimal. In addition, even if the chert is the main bed load component, it cannot account for the tendency of $S L$ values to increase downstream in the streams on the Salem Plateau. This is discussed in more detail in the section on "Discussion and Interpretation."

Many studies (for example, Leopold and others, 1964; Richards, 1982) have shown that slope is inversely proportional to discharge (equation 8). Field observations during the months of November 1983 and May 1984 showed that many reaches of fairly large streams were dry or had low flows. These observations would suggest that these reaches should have steep slopes. Many streams in the Salem Plateau section do not have slopes as high as might be expected. A particularly good example is the Spring River above and below Mammoth Springs (pl. 2). Flow from the spring averages about $9 \mathrm{~m}^{3} / \mathrm{s}$ (Vineyard and Feder, 1974). The flow of the Spring River at Hardy, Arkansas, $25 \mathrm{~km}$ south of Mammoth Spring, was $24.5 \mathrm{~m}^{3} / \mathrm{s}$ in May 1982 (Lamb and others, 1983). Assuming these rates of flow are representative over a long period of time, Mammoth Spring increases the flow of the Spring River by more than $\mathbf{3 0}$ percent, and logically might be expected to affect the profile of the river. However, no significant change in the profile is evident below the location of the spring. A counter example to the observation that reaches with low flows do not appear to have the expected steep slopes is Myatt Creek (pl. 2). Myatt Creek has a decrease in slope at about $30 \mathrm{~km}$ from the source. According to data from Harvey (1980, fig. 18), Myatt Creek is a "losing" creek in Missouri; that is, most or all of the water entering the creek goes into an underground flow system except during flood stages. About $30-\mathrm{km}$ downstream from its source, the creek flows even during low-flow stages. The abrupt change to a steeper slope, and perhaps the slight convexity of the stream profile upstream from the $30-\mathrm{km}$ point, is compatible with the normal lack of flow in this reach.

\section{Relationships of $S L$ Values to Lithology}

As noted in the previous section, lithology appears to influence the fluvial parameters of certain streams. Examples include the increase in $S L$ values with increase in bed load size and the decrease in $S L$ values where streams flow on alluvium. Ideally, the mineralogy, fabric, jointing, cementation, and attitude, as well as geometric relationships to other rock units, should be examined with respect to fluvial hydraulic parameters. For a study covering as large an area as does this study, however, it is not feasible to examine detailed lithologic factors. Instead, a broad-scale examination of the relationships of lithology to $S L$ is made.

$S L$ values appear to correlate very roughly with lithology. Figure 4 shows histograms of $S L$ values for each major lithology in the study area. No parametric tests for equality of means of the values in each histogram were made because of the great differences in the frequency distributions of the $S L$ values which range from highly skewed to bimodal. The data for the histograms were derived from plots of $S L$ versus distance on which geology from the annotated profiles was transcribed for all 66 streams. As might be expected, $S L$ values for streams flowing on shale and alluvium are slightly lower than those for sandstone; however, the difference is not large. The authors consider the $S L$ values to be surprisingly high for streams on limestone and dolomite. The high chert content in some formations (Jefferson and Cotter Dolomites) and the resulting chert bed load may account, in part, for the high $S L$ values. Consideration of the apparent trend of increasing $S L$ values downstream places more emphasis on tectonic causes for the unexpectedly high values (see the "Discussion and Interpretation" section of this report). The highest $S L$ values are for streams on sandstone, siltstone, and shale of the Hale Formation. The Hale Formation crops out in the Boston Mountains section, and as was noted earlier in this secton, the high $S L$ values may be due more to geologic structure or possibly tectonism than to lithology.

The above observations differ somewhat from observations of other authors on the relationship of lithology to erosion rates and slopes of streams, both of which affect $S L$ values. Young $(1969$, p. 851), for example, in a study of erosion rates concluded that "With respect to rock type, there are no marked differences in rates of erosion between igneous and metamorphic rocks, siliceous sedimentaries and limestones; ***." He further concluded that relief and past climatic conditions were major factors in determining rates of erosion. In contrast to the conclusions of Young (1969), Brush 


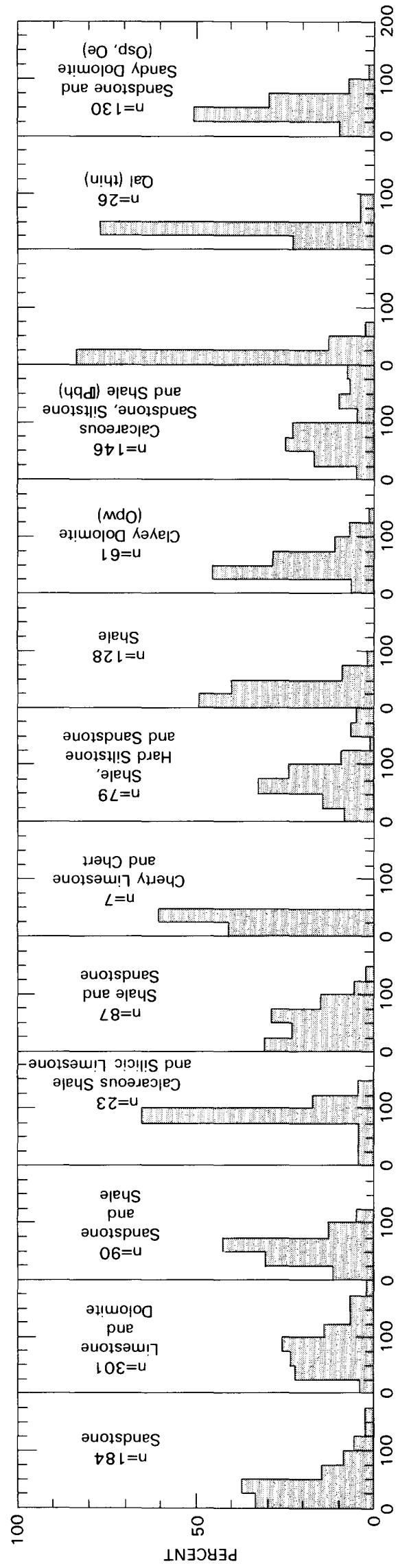

(1961), Hack (1957), and Morisawa (1962), for example, found that slopes of streams are affected by the lithology on which they flow. These studies were analogous to studies of Ozark Mountain streams reported herein, and similar results might be expected. Brush showed, from logarithmic plots of slope and stream lengths, that slope is dependent upon lithology. Brush's data will be discussed in more detail in a subsequent section of this report. In general, Brush found that slopes are higher for sandstone than for shale in agreement with Ozark data, but slopes for carbonate rocks in central Pennsylvania are not in agreement with those in carbonate rocks in the Ozarks. It is possible that the physical and chemical properties of carbonate rocks of central Pennsylvania studied by Brush are not the same as for the carbonate rocks of the Ozarks. A large difference seems very unlikely, however, because the carbonate rocks of both areas are Ordovician and karst development is common to both areas. Another similarity is that some of the carbonate rocks of central Pennsylvania contain abundant chert (Butts and Moore, 1936) as do some of the carbonate rocks of the Ozarks. An explanation of why lithology affects stream slopes differently in central Pennsylvania than in the Ozarks is not apparent to the authors, but some speculative explanations are given in the discussion section.

\section{Subenvelope Map}

A subenvelope map is valuable because it shows the topography on which streams are flowing in a region; land surface topography is essentially stripped away. A subenvelope map is constructed by contouring the elevations of the intersections of topographic contours with stream courses and was first devised by Stearns (1967). A subenvelope map will show drainage divides which may or may not coincide with divides suggested by landsurface topography. Hack (1973b), for example, has demonstrated, by use of a subenvelope map, that the drainage divide of the Appalachians is consistently east of the topographic divide and is not parallel to the structural trend of the Appalachians. Stearns (1967) used envelope, subenvelope, and structure contour maps to infer warping of the western highland rim peneplain in Tennessee by ground-water sapping. Two versions of a subenvelope map were constructed. One (fig. 5) was constructed by hand-contouring elevations along all stream courses shown on plate 1 . As the elevations were recorded at every contour, most of which were at 20 -ft-contour intervals, great detail and accuracy of streambed topography is achieved along the stream courses. Detail and accuracy are less in areas between streams because contours are interpolated. The second version was constructed by computer using a smoothing routine with the 


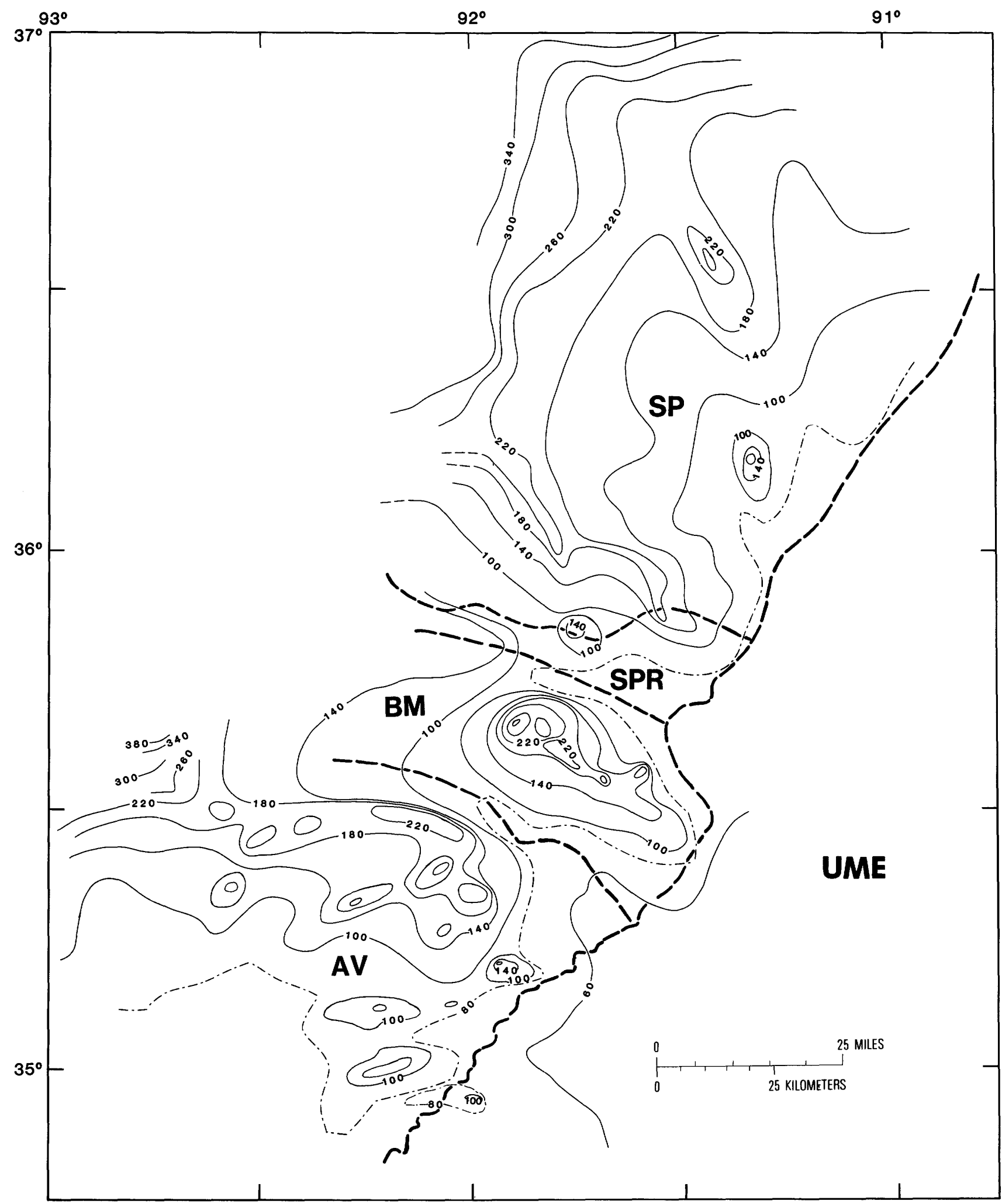

Figure 5. Subenvelope map derived by contouring a plot of elevation of streams at every topographic elevation along every stream course. Contour interval is $40 \mathrm{~m}$ except for one supplemental $20-\mathrm{m}$ contour shown as dash-dot line. Heavy-dashed lines are physiographic section boundaries. SP, Salem Plateau; SPR, Springfield Plateau; BM, Boston Mountains; AV, Arkansas Valley; UME, Upper Mississippi Embayment. 
requirement of minimum curvature (Webring, 1981) to produce a regular grid of elevations. The gridded elevations were in turn used to produce the gray-tone plot in figure 6. The general configuration of high and low elevations are very similar on both figures and indicate that despite the detail lost in producing a smoothed regular grid, little accuracy is lost.

The subenvelope maps of the study area show that the Salem Plateau section has a much larger area of high elevations over which streams flow than does the Boston
Mountains and Arkansas Valley sections. The maps also show that the subenvelope surface of most of the Salem Plateau dips to the southeast. With the exception of the Little Red River drainage, the subenvelope surfaces for streams in the Boston Mountains and Arkansas sections show more local variation in dip but with a general southerly dip. Structure and lithology may account for the differences in dip of the subenvelope surface. The general high elevation of streams on the Salem Plateau, however, cannot reasonably be explained by structure or

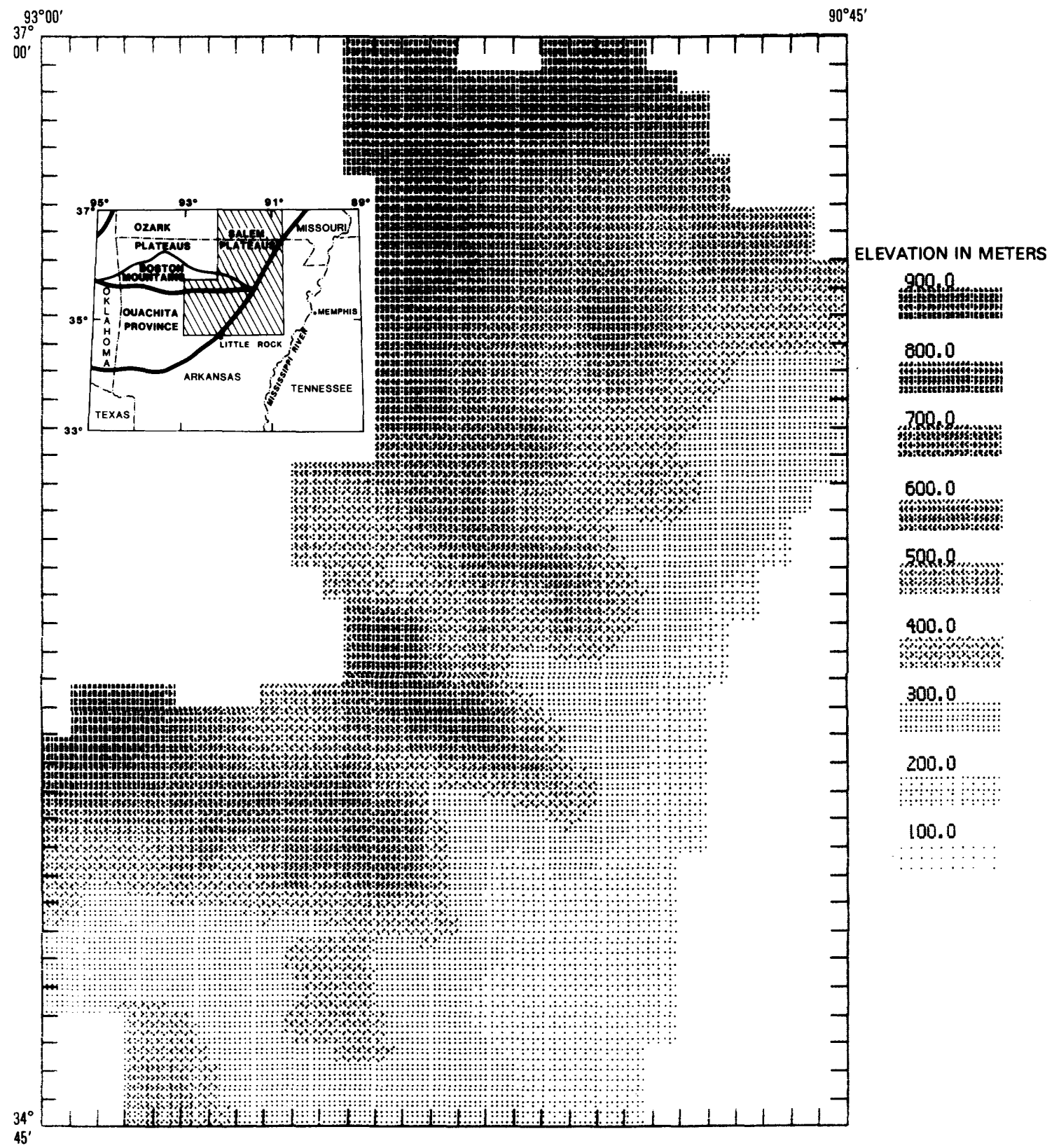

Figure 6. Subenvelope map produced from a plot of elevations of streams at every topographic elevation along every stream course and smoothed by a gridding program for plotting in gray tones. Grid size is $5.6 \mathrm{~km}$; centers of grid cells indicated by ticks within the neat lines. Latitude and longitude at corners of map are approximations because data are plotted in Cartesian coordinates and cannot be compared directly with other maps in this report. 
lithology. This observation will be discussed further in the discussion section of this report.

\section{Two-Dimensional Hypsometric Analysis}

Strahler (1952) devised a three-dimensional hypsometric integral $(H I)$ to analyze the relative amount of upland surface in a drainage basin in order to characterize and compare relative stages of development among basins. He states $(1952$, p.119) that $H I$ " **** expresses simply the manner in which the volume lying beneath the ground surface is distributed from base to top." Such an analysis, although desirable for the Ozark study area, is not feasible because the area is so large. Instead, a twodimensional hypsometric analysis was made to examine the relative amount of erosion along individual stream courses. The two-dimensional method consists of calculating the area under a stream profile by summing the horizontal areas between each contour interval and dividing by the rectangular area defined by the initial height times total length and expressed as percentage. The reader is cautioned that our definition of the $H I$ cannot be equated with the three-dimensional hypsometric analysis. The $H I$ provides a measure of erosion of a basin whereas the two-dimensional method provides a measure of the ground under a stream course.

These two-dimensional hypsometric percentages were then plotted at the midpoint of each stream course and contoured. The resultant map (fig. 7) shows that the Salem Plateau section has a larger percentage of ground remaining than either the Boston Mountains or Arkansas Valley sections. This result is compatible with the observation of the larger area of high elevations on the subenvelope map of the Salem Plateau section. Although the subenvelope map illustrates the elevations and topography of stream courses, and the two-dimensional $H I$ provides a measure of ground to be removed, they both suggest that streams on the Salem Plateau have not changed the average elevation and landscape as much as have streams in sections south of the plateau.

\section{Stream-Gradient Index (SL) Maps}

Previous examination of $S L$ values for selected streams from each physiographic section suggested differences among the sections. Further examination of the areal distribution of all $S L$ values upholds the suggested differences. Because $S L$ values show much local variation, it was necessary to smooth $S L$ values in order to look for regional differences. Two smoothing methods were used. One method, identical with that described in the previous discussion of the computer-generated subenvelope map, produced a rectangular grid of smoothed
$S L$ values which was then plotted using a gray-tone map (fig. 8). The other method produced a single $S L$ value for each stream. This $S L$ value was calculated by dividing the total relief of the stream by the ln of the total length. These total stream $S L$ values were plotted midway along each stream course and then contoured to produce figure 9. This latter smoothing method is limited in that it does not take into account the shape of the stream profile. Nevertheless, it does provide a normalized measure of $S L$ for a whole stream and is in overall agreement with the previous smoothing method. Both resulting maps show a large area of the Salem Plateau section having relatively high $S L$ values, a small area of the Boston Mountains section having high $S L$ values, and the Arkansas Valley section having relatively low $S L$ values. The low values for the Salem Plateau in the northeast corner of figure 8 are not real. The streams digitized in that part of the study area are too far apart for the size of the grid used to smooth values. Thus the $S L$ maps support the difference among the three physiographic sections on the two-dimensional hypsometric and subenvelope maps, implying that fundamentally different geomorphic history and processes have shaped these areas.

\section{Stream Length, Slope, Drainage-Basin Area, and Flow Relationships}

Several of the variables most commonly used to examine drainage basin morphology are stream length $(L)$, slope $(S)$, discharge $(Q)$, and drainage-basin area $(A)$. Empirical relationships among them have been used to describe quantitative differences in stream characteristics related to lithology, as well as to describe some relatively constant characteristics which seem to be independent of stream length, drainage basin area, and lithology. Consequently, relationships between stream length and slope for different lithologies are of particular importance to this report because they can be compared with similar data reported in the literature.

Documentation and analysis of large amounts of fluvial morphologic data are rare. A search of the literature indicates that some work by Brush (1961) and by Shimano (1975) are exceptions. Brush's study of 16 streams along which he measured 16 variables, including stream length, slope, drainage area, and lithology at 119 localities is unusual both for the amount of data and the scope of the analyses of them. Shimano (1975) compiled and analyzed a large amount of data on drainage basin area and main stream length in Japan for a study of Hack's law and confirmed it for the areas studied. He made several hundred measurements of stream length and drainage-basin areas in 155 drainage basins larger than fifth order in Japan. The Ozark study includes hundreds of measurements of stream length and slope, and 


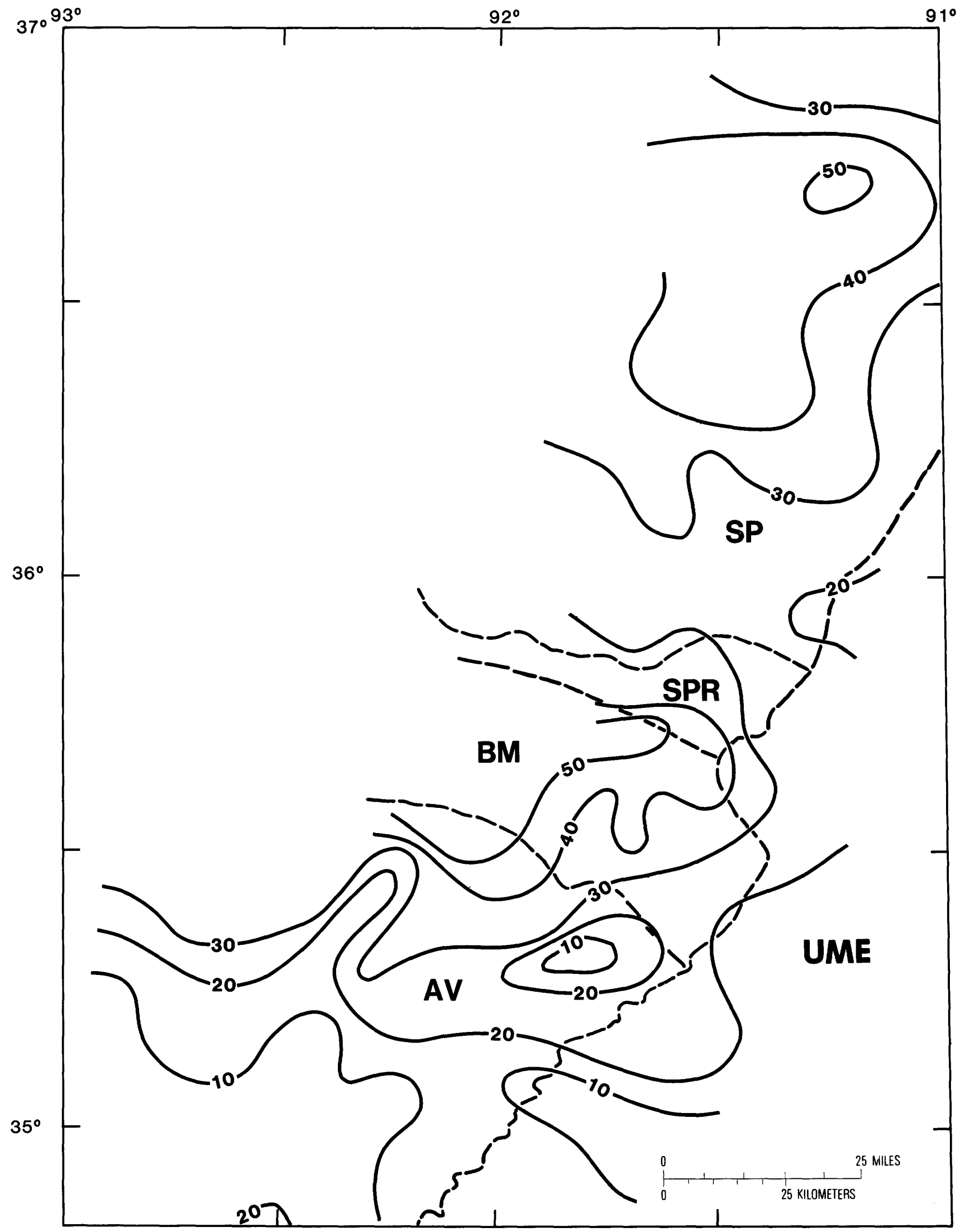

Figure 7. Contour map of two-dimensional hypsometric values plotted midway along stream courses and calculated for the whole reach of each stream. Heavy-dashed lines are physiographic section boundaries. SP, Salem Plateau; SPR, Springfield Plateau; BM, Boston Mountains; AV, Arkansas Valley; UME, Upper Mississippi Embayment. 


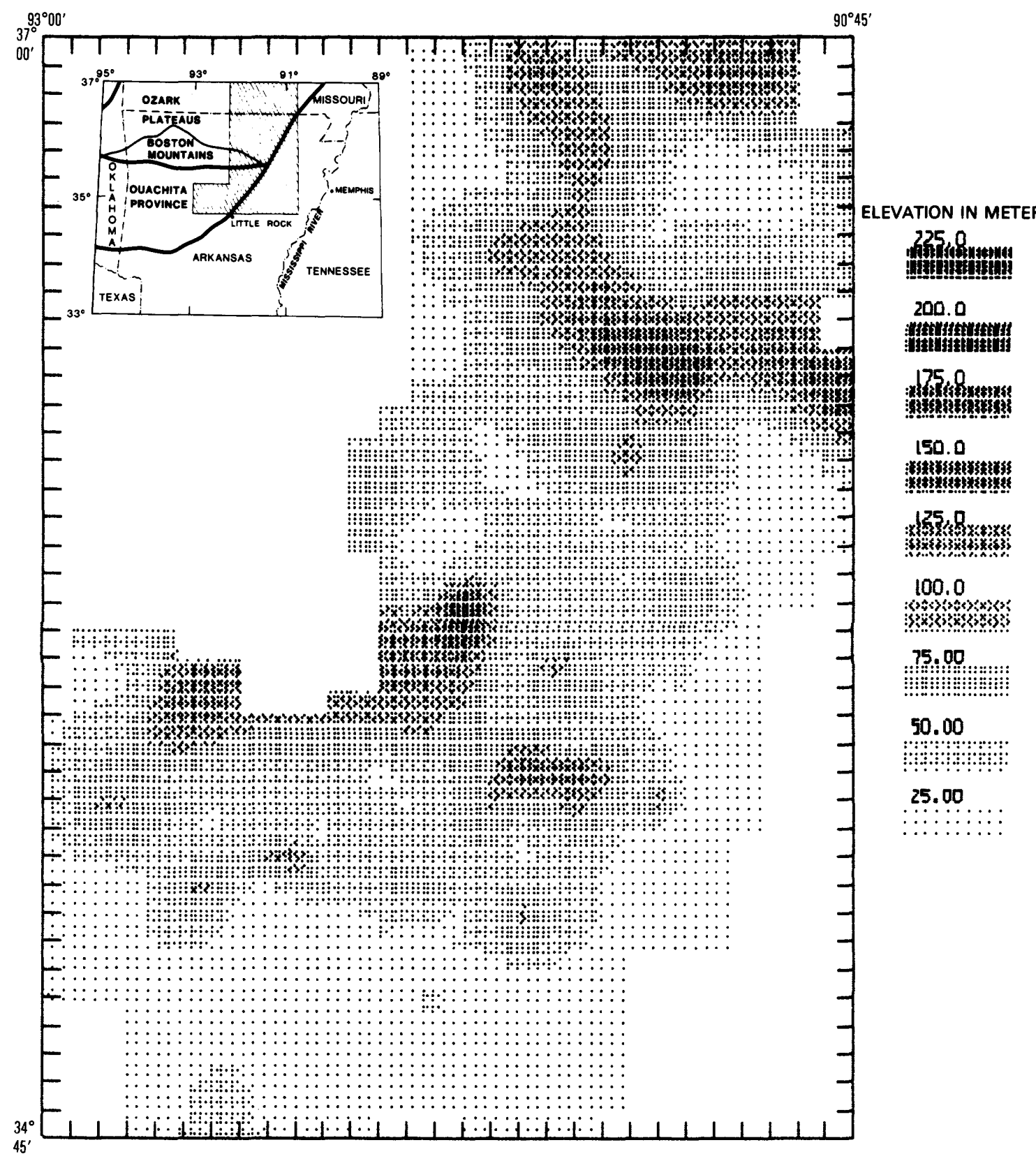

Figure 8. Stream-gradient index values calculated for reaches between every elevation contour and smoothed by a gridding program for plotting in gray tones. Grid size is $5.6 \mathrm{~km}$; centers of grid cells indicated by ticks within the neat lines. Areas without pattern are outside of mapped area or have no data within a 10-km radius of the grid center. Latitude and longitude at corners of map are approximations, because data are plotted in Cartesian coordinates and cannot be compared directly with other maps in this report.

hundreds of lithologic descriptions, but very few measurements of discharge and basin area.

\section{Relationships of Stream Length, Slope, and Lithology}

Least-squares regression equations were calculated for stream length and slope data from this study and from studies of Brush (1961, app. A), where length was the independent variable. In addition to analyzing all data obtained for both studies, the data were divided into sets representing the three lithologic provinces of the Ozarks and the three similar lithologic units used by Brush where they were identifiable. Brush supported this hypothetical stream concept by showing that data from individual 


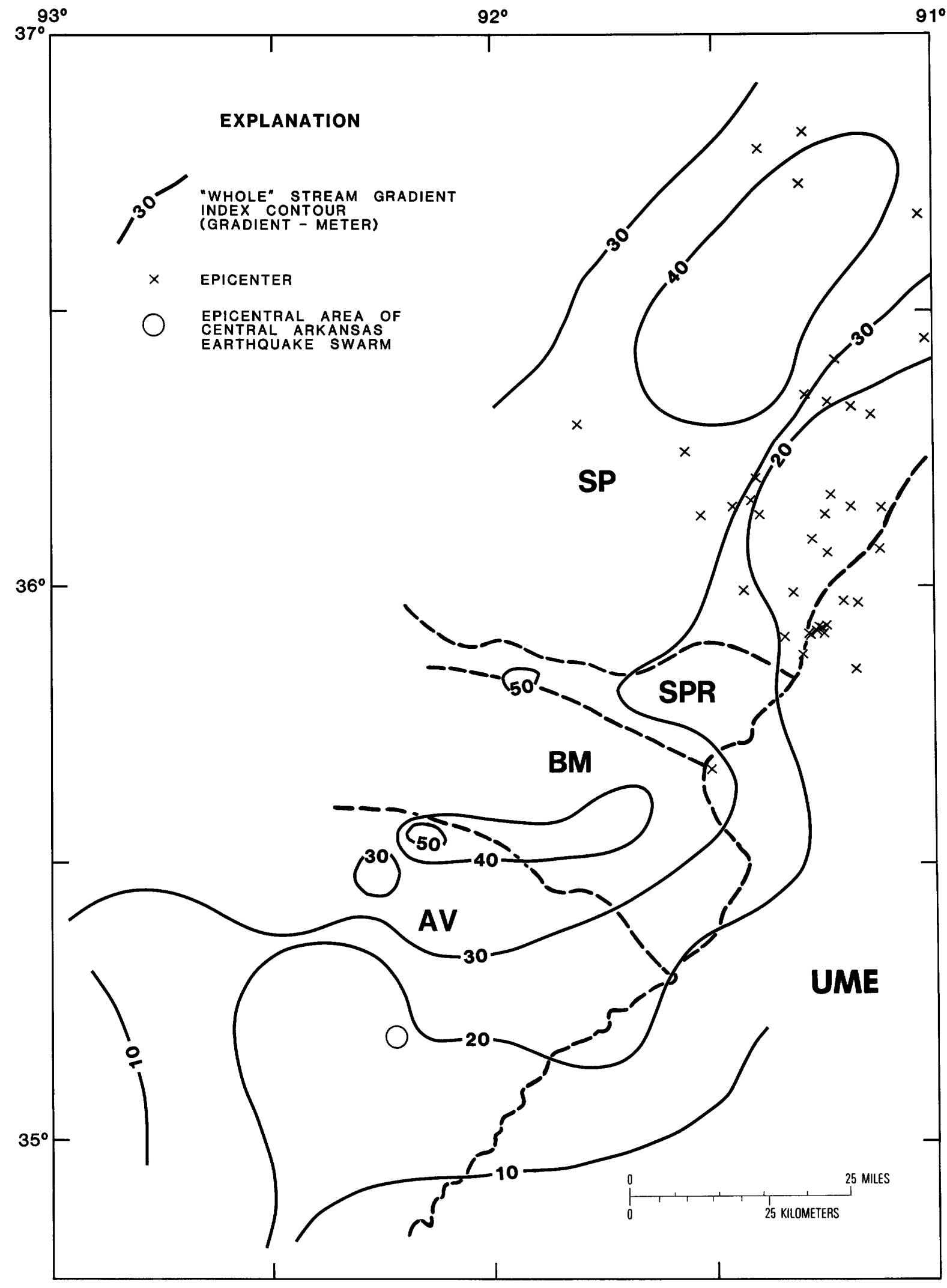

Figure 9. Contour map of SL values plotted midway along stream courses and calculated for the whole reach of each stream. Heavy-dashed lines are physiographic section boundaries. SP, Salem Plateau; SPR, Springfield Plateau; BM, Boston Mountains; AV, Arkansas Valley; UME, Upper Mississippi Embayment. 
stations along a number of different streams when plotted as a composite set have definite trends (Brush, 1961, p. 161). The regression equations and coefficients of correlation from the least-squares analysis are given in table 1:

Table 1. Regression equations and coefficients of correlation for logarithmic plots of slope and stream length of streams in the study areas of the Ozark region (this report) and central Pennsylvania (Brush, 1961)

$[S$, slope; $L$, length of stream in meters; $r$, coefficient of correlation; $N$, number of data points]

\begin{tabular}{|c|c|c|c|}
\hline Data & Regression equation & $r$ & $N$ \\
\hline $\begin{array}{l}\text { All data from this study } \\
\text { except the Arkansas, } \\
\text { Black, and White Rivers } \\
\text { and Meto and Watten- } \\
\text { saw Bayous ......... }\end{array}$ & $S=0.960 L^{-0.606}$ & 0.732 & 1,855 \\
\hline All data from Brush ... & $S=.035 L^{-0.799}$ & .826 & 118 \\
\hline Salem Plateau $\ldots \ldots \ldots$ & $S=.239 L^{-0.463}$ & .760 & 738 \\
\hline Boston Mountains ..... & $S=8.94 \quad L^{-0.790}$ & .750 & 420 \\
\hline Arkansas Valley ....... & $S=1.553 L^{-0.693}$ & .803 & 697 \\
\hline Sandstone (Brush) & $S=6.47 \quad L^{-0.67}$ & .76 & 19 \\
\hline Shale (Brush) & $S=13.45 \quad L^{-0.81}$ & .87 & 13 \\
\hline $\begin{array}{c}\text { Limestone and dolomite } \\
\text { (Brush) } \ldots \ldots \ldots \ldots\end{array}$ & $S=3.59 L^{-0.71}$ & .78 & 15 \\
\hline
\end{tabular}

Note that the sum of the data points for the lithologic units of Brush do not add up to the 118 data points for all of Brush's data. Only monolithologic data of Brush were used because without more detailed knowledge of his data we did not feel justified in categorizing his multilithologic data into one lithology as we did for the Ozark study.

The regression lines are plotted on figures 10 and 11. Two notable aspects of these figures warrant comment. First, the stream slopes represented by the lines on figure 10 are quite different. The regression line for the Brush data shows higher values of stream slopes for a given length than does the regression line for the Ozark data. This difference is probably due to sampling differences between the two studies. In an effort to collect data from similar streambed environments Brush collected samples and made measurements only in riffled sections of streams. As he noted on page 148, riffled sections have “*** gradients greater than that of adjacent segments of the stream." Consequently, his slopes would tend to be greater than slopes sampled at random or equally spaced locations along a stream. As explained under the section on methods, stream lengths and slopes for the Ozark study were calculated at every elevation contour crossing the stream, providing a more representative sample of stream lengths and slopes.

The same sampling bias accounts for most of the differences in stream slopes in figure 11 when individual lithologies are examined. For the most part, each lithology described in Brush's study has higher stream slopes at a given length than does the corresponding lithology from our study. The limestone-dolomite regression lines are exceptions. These exceptions appear to be due to a fundamental difference in the limestone-dolomite slope-length relationship of the Salem Plateau. It differs from all others including those of Brush's study. This brings us to the second notable aspect of the regression analysis of slope versus length.

With one exception, the slopes (that is, the exponents of the regression equations) of all of the regression lines on figure 11 are very much alike; the exponents on length range from only about -0.7 to -0.8 regardless of lithology. Brush (1961, p. 164) noted this in his data. That the sandstone and shale of two of the Ozark physiographic sections show the same range in exponents suggests that changes in slope as a function of length are similar regardless of lithology both in central Pennsylvania and in the Ozarks.

The exception is the slope of the regression line for the limestone and dolomite terrain of the Salem Plateau section. Here, the exponent on length is -0.463 . The decrease in slope with length on this line is so small that from 3.5 to $100 \mathrm{~km}$ the slope of streams on the Salem Plateau becomes increasingly greater than that of all other streams except those on sandstone in central Pennsylvania. An apparent similar slope-stream length relationship is indicated in figure 45 of Hack (1957) not only for limestone and dolomite but also for schist and granodiorite. The similarity in slopes of the slope-stream length plots for limestone and dolomite on the Salem Plateau and the limestone and dolomite in the Valley and Ridge province in Virginia where Hack made measurements is not as close as it may seem, however. Calculation of a regression equation and coefficient of correlation for the 18 limestone and dolomite data points for streams greater than $6 \mathrm{~km}$ in table 8 of Hack (1957) yields

$$
\begin{aligned}
& S=0.961 L^{-0.595} \\
& r=-0.657 .
\end{aligned}
$$

The exponent on $L$ suggests that the slope-stream length relationships for the two areas may be different. However, the low coefficient of correlation for the Valley and Ridge province data suggests that comparison of it with the Salem Plateau data may not be appropriate.

\section{Relationship of Streamflow to Drainage Area}

It is well known that the Salem Plateau has abundant sinkholes and a large underground flow of water (see, for example, Vineyard and Feder, 1974; Harvey, 1980). The anomalous slope-stream length relationship of streams on the plateau might, therefore, be explained by some uncommon flow characteristics of the streams. This concept was reinforced somewhat because field 


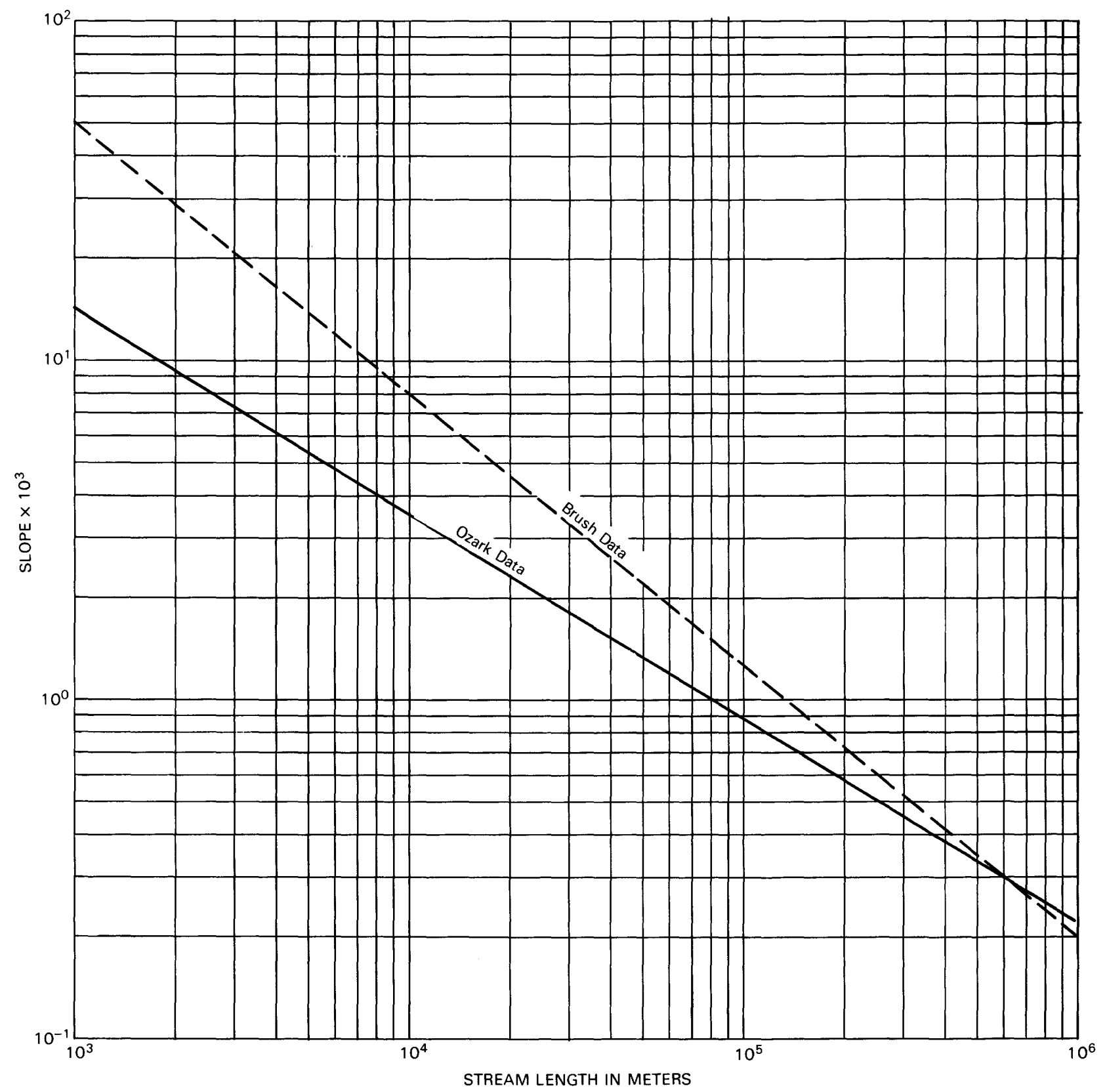

Figure 10. Regression lines for all slope- and stream-length data from Brush (1961) and the Ozark study area.

examination of the upper halves of Hurricane Creek, Spring River, and Spring Creek during November 1983 and May 1984 showed parts of them to be dry and other parts to have very little water flowing in them. It was evident, however, that these streams and others not described in this report had much water flowing in them at other times, because their valleys are wide and their beds contain abundant gravel and lack vegetation.

As brief field observations of streamflow can be misleading, the available data on flow and drainage basin area were compiled for the Salem Plateau (table 2). Flow and basin area data for streams south of the Salem
Plateau in the study area are too few for statistical treatment.

The regression equation for the data in table 2 is

$$
Q=.008 A^{1.04}
$$

The coefficient of correlation $(r)$ for the equation is

$$
r=0.99
$$

The analysis agrees closely with other studies of flow versus basin area relationships. Leopold and others (1964) 


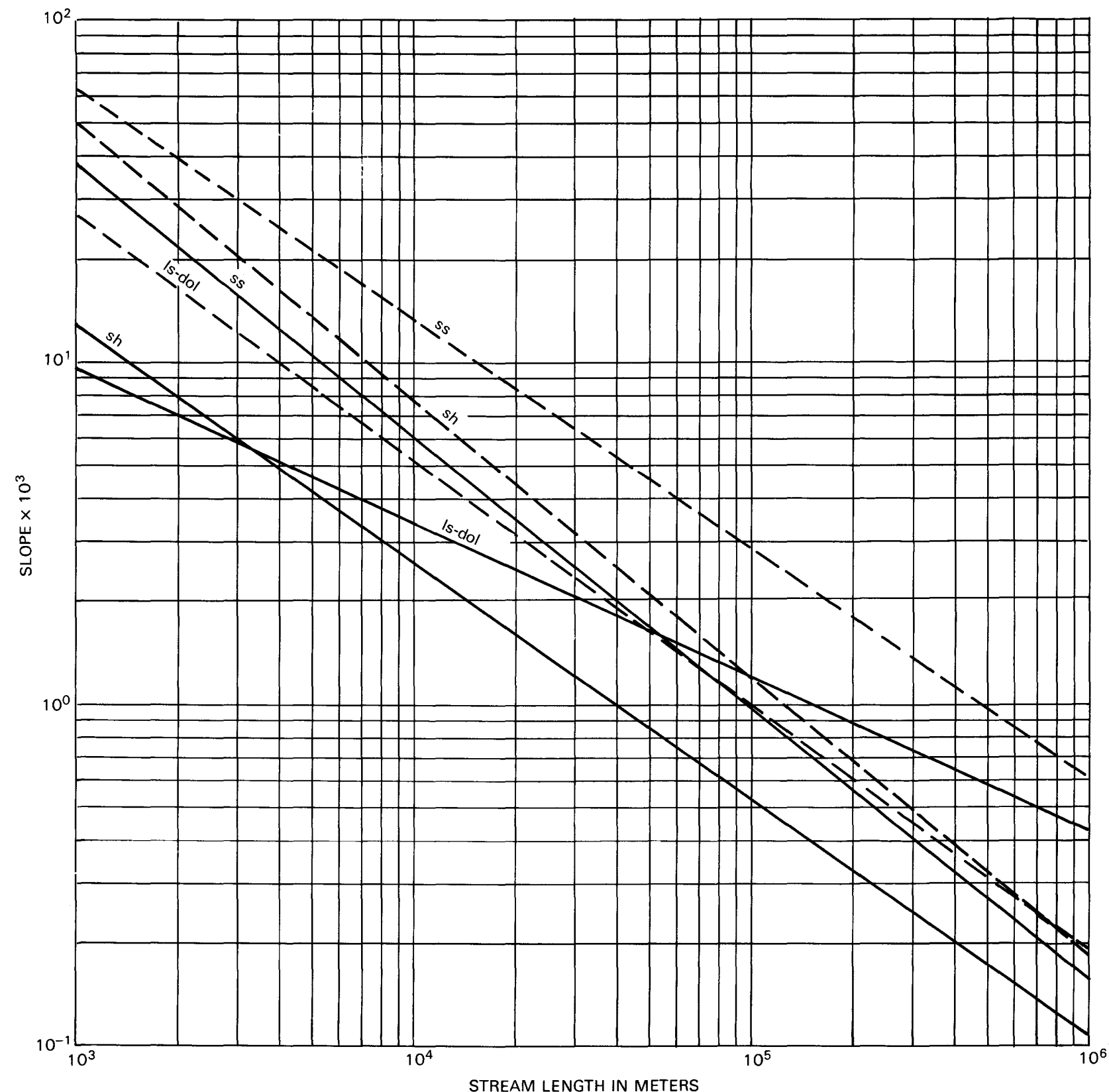

Figure 11. Regression lines for slope and stream-length data for sandstone (ss), shale (sh), and limestone and dolomite (Is-dol). Dashed lines from Brush (1961); solid lines are data from this report.

give the relationship between bankfull flow $\left(Q_{b}\right)$ and basin area (A) as

$$
Q_{b} \propto A^{0.75}
$$

They state, however, that the exponent is about 1.0 for mean annual flow in humid regions, which is consonant with the exponent on $A$ in the regression equation.

The above data and analyses strongly suggest that the anomalous relationships between slope and length of streams on the Salem Plateau cannot be explained by uncommon flow characteristics of the streams even though much of the flow during part of the time is underground. This is not surprising, because it is commonly recognized that modification of stream hydraulics occurs primarily during bankfull or greater flow stages (Leopold and others, 1964).

\section{DISCUSSION AND INTERPRETATION}

The primary objective of this study was to identify regions of active crustal strain using quantitative fluvial geomorphic data in a synoptic mode. The authors are 
Table 2. Average flow and drainage-basin area for some streams on the Salem Plateau [From Lamb and others (1983) and Waite and others (1983). $Q$, mean annual flow for periods of time ranging from 6 to $70 \mathrm{yrs}$, depending upon which stream is considered]

\begin{tabular}{|c|c|c|}
\hline & $\begin{array}{l}\text { Average } \\
\text { flow }(Q) \\
\text { (cubic meters } \\
\text { per second) }\end{array}$ & $\begin{array}{l}\text { Drainage-basin area }(A) \\
\text { above location of } \\
\text { streamflow measurement } \\
\text { (square kilometers) }\end{array}$ \\
\hline Black River & 236.0 & 19,090 \\
\hline Current River & 52.2 & 4,318 \\
\hline Do $\ldots \ldots \ldots \ldots \ldots \ldots \ldots \ldots \ldots \ldots$ & 76.1 & 5,278 \\
\hline Eleven Point River $\ldots \ldots \ldots \ldots \ldots \ldots \ldots$ & 21.2 & 2,050 \\
\hline Do $\ldots \ldots \ldots \ldots$ & 31.4 & 2,937 \\
\hline Fourche Creek ....... & 2.6 & 226 \\
\hline Piney Fork Creek $\ldots \ldots \ldots \ldots \ldots \ldots \ldots$ & 2.5 & 257 \\
\hline Spring River $\ldots \ldots \ldots \ldots \ldots \ldots \ldots \ldots \ldots$ & 6.9 & 793 \\
\hline Do $\ldots \ldots \ldots \ldots \ldots \ldots \ldots \ldots \ldots$ & 23.7 & 3,015 \\
\hline Do $\ldots \ldots \ldots \ldots \ldots \ldots \ldots \ldots \ldots \ldots$ & 38.0 & 3,064 \\
\hline Strawberry River ... & 14.2 & 1,225 \\
\hline White River ...... & 630 & 51,440 \\
\hline 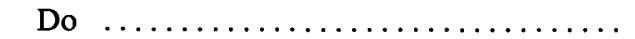 & 845 & 66,187 \\
\hline
\end{tabular}

unaware of any similar studies with the same objective for as large an area as the eastern Ozark Mountains region or as large a body of information. Hack's (1973b) analyses of $S L$ in the Winston-Salem, N.C., $2^{\circ}$ quadrangle is probably most analogous to the Ozark study and, indeed, was the principal stimulus to undertake it. The work of Keller (1977), Keller and Rockwell (1984) in the San Gabriel Mountains, and of Michele Miller (written commun., 1983) in the Santa Cruz Mountains of California are quite analogous to the Ozark study in both the objective and methods employed. They were reasonably successful in identifying "cells" of tectonic activity using $S L$ 's and in taking into account rock type and known faults. Their study areas and variety of methods, however, were very much smaller than those of the Ozark study.

In a study of stream profiles using $S L$ 's of large streams flowing out of the Himalayan Mountains, Seeber and Gornitz (1983) interpreted crustal deformation associated with uplift of the mountains and seismicity. Their study, although somewhat analogous, used much less detailed information than was obtained for the Ozark study. As no completely analogous study is known to the authors and there is no unambiguous evidence (except for current seismicity) to prove or disprove active tectonism in the Ozarks, evaluation of the success or failure of the study will be heuristic. It is clear that no one set of data provides a definitive answer, but circumstantial evidence described below indicates that the Salem Plateau section was recently, or may yet be, tectonically active.

Plots of $S L$ values (figs. 8,9) on maps show that the Salem Plateau section has a larger area of higher $S L$ values compared with the other sections in the Ozark study area. Further, the log-slope versus log-stream length plots (fig. 11) show that the slope of streams on the Salem
Plateau decreases at a markedly lower rate than do other streams in the study area and at a lower rate than streams in an analogous region in central Pennsylvania. In addition to the apparent unique $S L$ and slope characteristics of streams on the Salem Plateau, the subenvelope map (figs. 5, 6) and the two-dimensional hypsometric analysis (fig. 7) suggest that the plateau is quite different from the physiographic sections south of it. The subenvelope maps show that streams on the plateau are flowing on a large area of high elevation, which has not been dissected as much as the areas south of the plateau. The two-dimensional hypsometric analysis also shows much the same status of erosion, namely that the streams on the plateau have more rock to erode and have not modified the landscape as much as the streams south of the plateau. Altogether these apparent unique characteristics of the Salem Plateau suggest that it has a physiographic and possibly a tectonic history different from the physiographic sections south of it. The apparent $S L$ and slope anomalies need to be considered in more detail, however, before accepting them as unique, because it is possible that they may be explained by nontectonic factors.

Cursory examination of the distribution of $S L$ values on the Salem Plateau and their relationship to lithology suggests that the values are relatively high because of the high content of chert in some formations over which some streams on the plateau flow. As stream slopes and $S L$ values are a function of more than lithology and bed load, a more comprehensive examination of the data on slopes is warranted.

As noted in the section on the relationship of lithology to $S L$ values, chert in the limestone and dolomite of the Jefferson City and Cotter Dolomites and in the sandstone of the Roubidoux Formation may account for 
the high $S L$ values of these formations. Streams flowing on these formations have bed loads composed largely of chert. The chert is not likely to decrease rapidly in size by abrasion as it is moved downstream. Leopold and others $(1964$, p.254) state “*** where particle size increases downstream the profile has a small concavity. If the rate of increase of particle size downstream is large enough, the profile is a straight line or may even be convex to the sky." Convex parts of Glaise Creek, Fourteenmile Creek, and N Big Creek in the Boston Mountains section (pl. 2) as well as other streams profiled for this report but not illustrated are examples of the above citation. The convex parts or small decreases in slope downstream for these streams, however, occur where the size of the sandstone in the bed load increased downstream by several tens of centimeters in greatest dimension. No suggestion of an increase downstream in size of material in the bed load was noted in cursory field observations of streambeds on the Salem Plateau. The size of fragments generaly range from a few to as much as 20 centimeters in their greatest dimension. At places along Eleven Point River about 20 percent of the bed load is hard sandstone, presumably from the Roubidoux Formation through which the river flows in its upper reaches. The sandstone has about the same range in size as the chert. Like the chert, these fragments are rounded from abrasion and certainly must decrease in size downstream. The rate of decrease is unknown, but the sandstone fragments were very likely from blocks that were much larger where they first entered the river and that have undoubtedly decreased in size.

The effect of change in size of bed load material on $S L$ values can be estimated from equation 6 if a constant $(B)$ is included to make the equation an equality instead of a proportionality as shown below.

$$
S L=B M^{0.6}
$$

Ratios of different sizes of bed load material and SL values may then be expressed as

$$
\frac{S L_{1}}{S L_{2}}=\frac{B M_{1}^{0.6}}{B M_{2}^{0.6}}
$$

which reduces to

$$
\frac{S L_{1}}{S L_{2}}=\frac{M_{1}^{0.6}}{M_{2}^{0.6}} .
$$

An example of the use of this equation is the calculation of $S L$ value where a large change in bed-load size occurs along Tenmile Creek (pl. 2). A sharp change in the profile and $S L$ values of this creek occur at about elevation $130 \mathrm{~m}$. The size of the bed-load material upstream $\left(M_{1}\right)$ of this elevation is estimated to be about $10 \mathrm{~cm}$ in maximum dimension. The $S L$ value $\left(S L_{1}\right)$ immediately upstream of this elevation is 60 (pl. 2). Downstream from elevation $130 \mathrm{~m}$, the bed-load material $\left(M_{2}\right)$ is estimated to be $100 \mathrm{~cm}$ in maximum dimension. The downstream $S L$ value $\left(S L_{2}\right)$ calculated from the above values is:

$$
\begin{aligned}
& \frac{60}{S L_{2}}=\frac{10^{0 \cdot 6}}{100^{0 \cdot 6}} \\
& S L_{2}=239
\end{aligned}
$$

This $S L$ value is close to the $S L$ value (215) at elevation 115 (pl. 2) calculated from the elevation and length measurements.

Estimates of the size of bed-load material in streams with abundant chert on the Salem Plateau indicate that size probably decreases downstream. However, even if no change in size occurs downstream, $S L$ values would decrease or remain the same. The fact that $S L$ values tend to increase downstream in streams on the Salem Plateau (pl. 2) strongly indicates that chert has little affect on the $S L$ values of these streams.

Examination of the profiles of streams studied in this report also suggests no simple relationship between slope and size of fragments in the bed load of a stream. The qualitative similarity in concavity of profiles of streams with abundant chert pebbles and with little or no chert, but with much finer grained material (for example, Spring River and Strawberry River) suggests that some factor(s) control slope in addition to size of fragments in the bed load.

The validity of conclusions drawn from a comparison of the logarithmic plots of slope and stream length (fig. 11) for streams in the Ozark region with similar plots for streams in central Pennsylvania may be questionable because of the differences in the structural environment of the two areas. This is particularly true for the limestone-dolomite plots. The rocks in the Ozark region are not folded and have low dips, whereas similar rocks in central Pennsylvania are folded and locally have steep dips. As stated in the section on the "Relationship of stream length, slope and lithology," however, the plots of slope and stream length for the three categories of lithology represent hypothetical streams. The similarity of the exponents for curves of sandstone and shale in the Ozark region with the exponents for curves of sandstone and shale in the central Pennsylvania area indicates that comparison of data representing hypothetical streams is valid. The exponents of curves for limestone and dolomite in the two areas therefore should also be comparable. The smaller exponent of the limestone-dolomite curve for the Ozark region indicates that the slope of the streams is decreasing downstream at a lower rate than for streams in central Pennsylvania. A lower rate of decrease in slope 
would be expected for streams flowing off of a dome if they have not reached an equilibrium between erosion and uplift rates of the dome. This reasoning is based upon the fact that the slope of the surface of a dome, whether it is spherical or ellipsoidal, increases with distance from its apex. Any stream, therefore, flowing off of a dome that is rising at a rate greater than the rate of erosion would have a greater slope downstream than if equilibrium rates of uplift and erosion had been established.

Streamflow was also considered as a possible cause of changes in slope. Comparison of profiles and qualitative observations of flow along several streams on the Salem Plateau showed that large changes in normal flow along a stream do not produce the expected changes in profiles. The profile of the Spring River downstream from the entry of flow from Mammoth Spring provides one of the most convincing examples. The slight increase in slope downstream from the spring (pl. 2) is just the reverse of what would be expected; an increase in flow should cause a decrease in slope.

More germane to the objective of this study are possible explanations of the $S L$ values, stream slopes, subenvelope map, and the hypsometric analysis characteristic of a region rather than characteristic of selected streams. More than lithology, streamflow, and structure is needed to explain the uniqueness of the above attributes for the Salem Plateau. Other explanations that warrant consideration are change in base level or uplift of drainage basins.

A change in base level could have occurred as the result of changes in sea level during the Quaternary. However, whatever the effect of change in base level had on streams would be common to streams in all three physiographic sections and not just those in the Salem Plateau section.

The most logical remaining explanation for the geomorphic and fluvial characteristics of the Salem Plateau is that uplift of the plateau has occurred in the recent past. Amount and time of uplift will determine whether it is influencing current seismicity.

\section{Possible Time of Uplift of the Ozarks}

Post-Tertiary uplift of the Ozark dome has been postulated by a number of investigators. Hershey (1895) and Marbut (1896) were the first to recognize that the dome had at least one and perhaps several periods of uplift. A good history of the concepts of post-Tertiary uplift and their authors is given in Bretz (1965). The principal argument used by nearly all of the investigators was that the concordant surfaces evident on the Salem and Springfield plateaus of the Ozarks represent Tertiary peneplains. Much controversy still exists among the many investigators over the number of peneplains, their extent, periods of uplift, and whether the surfaces are remnants of peneplains at all. The surfaces, whatever their origin, dip away from the apex of the Ozark dome and are erosional surfaces into which streams are incised. The time of incision, if known, would place a minimum age on uplift. Some investigators like Potter $(1955, \mathrm{p} .128)$ believe epeirogenic uplift occurred in the Pliocene, Flint (1941) argued that uplift was post-Wilcox (Eocene) and preglacial, and Shaw (1915) argued for uplift in the Pleistocene. Several kinds of evidence and reasoning pertinent to the history of uplift of the Ozark Plateaus are given below.

It is apparent from study of the literature that no one yet has evidence for a definitive geomorphic history of the Ozark Plateaus. It is also obvious from the literature that establishing the age of "Lafayette" gravel to the Citronelle Formation of the Gulf Coast would be a major contribution to the geomorphic history of the region, because the Lafayette locally contains clasts from rocks that underlie the Salem Plateau and, therefore, are indicative of time of uplift of the plateau. The authors are inclined to believe that the Lafayette Gravel in western Kentucky and Crowleys Ridge (fig. 1) of Potter (1955) are temporally correlative with the Citronelle Formation of the eastern Gulf Coast and Atlantic Coast as far north as Virginia. Early maps of these regions show Lafayette as widespread gravel and sand deposits, which are not mapped as the Citronelle Formation. Some fossil evidence suggests a Pleistocene age for all or part of the Citronelle Formation but is not conclusive (Doering, 1960). A stronger argument for a Pleistocene age is stated by Doering (1960, p. 199): “The distinct separation by unconformity of the formation [Citronelle] from the preceding Tertiary formations and the lithologic resemblance to the succeeding Pleistocene formations are arguments for the latter choice [preglacial Pleistocene age]." The evidence described by Doering does not preclude a Pliocene age for the gravel, but it does show that the gravel is unconformable on Miocene rocks everywhere and is therefore younger than Miocene. The inferred history and provenance of the Citronelle along the East Coast and the Lafayette in western Kentucky suggests that the Citronelle Formation and the Lafayette west of the Appalachian Mountains may be temporally if not stratigraphically correlative. Doering (p. 200) believes that the Citronelle “**** was deposited as a detrital apron of the Blue Ridge-Appalachian Mountain region following elevation of that region at the end of the Pliocene and the beginning of the Quaternary."

Potter (1955, p.129) interprets the Lafayette Gravel of western Kentucky and Crowleys Ridge as a composite fan with different provenances. The mineralogy of the gravel and sand of the Lafayette in western Kentucky suggests that it came from the Blue Ridge province. The source of the Crowleys Ridge Lafayette was platform 
sediments of the continental interior and the Ozark Mountains to the west.

In a study of the Jackson Purchase region of western Kentucky, Olive (1980) concluded that gravel of two ages occurs there. He based his conclusions on the ages of pollen samples, stratigraphic relationships, and cementation characteristics. The older gravel fills incised valleys, contains pollen of Miocene(?) and Pliocene age, and does not contain iron oxide-cemented clasts. At another location, gravel containing iron oxide-cemented clasts and overlain by loess of Wisconsinian age is inferred to be of Pleistocene age, because Pleistocene pollen was found in a bed of clay inferred to be interbedded with the gravel. The stratigraphic relationship of the clay and gravel is not certain, but Olive $(1980$, p. 3) infers " *** that gravel deposits in other parts of the region that contain cemented gravel clasts and are overlain by loess are also Pleistocene in age." The gravel on Crowleys Ridge is overlain by loess, contains iron oxide-cemented clasts, and therefore is reasonably interpreted to be of Pleistocene age.

Past sea levels may add another constraint to the age of the Lafayette Gravel. The elevation of the base of the gravel on Crowleys Ridge near the mouth of Wattensaw Bayou is about $120 \mathrm{~m}$. At the north end of Crowleys Ridge the elevation of the base of the gravel is about $150 \mathrm{~m}$. Because the gravel is of continental origin and was never covered by marine sediments, it can be no older than the time that the sea level was no higher than about $100 \mathrm{~m}$. The authors recognize that sea levels are a function of astronomical periodicities, volume of oceans as related to rate of sea-floor spreading, glacial cycles, and perhaps other unrecognized forces. Nevertheless, interpretation of available data in light of current concepts suggests that sea levels were not low enough until postMiocene and probably post early Pliocene for deposition of the Lafayette Gravel (Zuener, 1959; Holmes, 1965, p. 713).

\section{Inferred 'Rates of Uplift of the Ozarks}

If the above arguments for the beginning of uplift of the Ozarks since early Pleistocene, late Pliocene, or early Pliocene are correct, the rate of uplift can be estimated and compared with rates of uplift of other topographically high areas. In order to calculate rate of uplift, however, some additional information must be considered so that an estimate of the base level from which uplift started can be made. As stated above, both Potter and Doering interpret deposits of the Lafayette Gravel and the temporally equivalent Citronelle Formation to be large composite alluvial fans whose various parts have different provenances. The gravel of the Lafayette on Crowleys Ridge is composed largely of chert, vein quartz, and metamorphic quartz (Potter, 1955). As the chert commonly has casts of fossils like those in rocks underlying the Ozark Plateaus, the source of the chert is presumed to be the plateaus. The direction of crossbedding in the gravels also indicates a source on the plateaus (Potter, 1955). The gravel does not contain any carbonate rocks or igneous rocks despite the fact that the Ozarks are largely underlain by such rocks. The lack of carbonate rocks suggested to Potter $(1955, \mathrm{p} .31)$ that "**** Lafayette streams had access to a source area that was deeply weathered ***." The absence of igneous rock in the Lafayette of Crowleys Ridge may indicate that igneous rocks in the Ozarks were not yet exposed by erosion in Lafayette time.

Deep weathering implies that the area had little relief for a long period prior to erosion of it. The incised meanders and patterns of streams on the Ozark Plateaus also suggest little relief at some time in the past. Flume experiments reported by Schumm (1977, p. 199-200) suggest that incised meanders do not inherit their patterns from a warped peneplain as might be expected. He argues that meanders developed in alluvium become incised into bedrock as the result of lowering of base level or vertical uplift. The many triple junctions of drainage basins and the dendritic drainage patterns of streams on the Ozark Plateaus, as shown on U.S. Geological Survey (USGS) hydrologic maps of Arkansas and Missouri, also suggest low relief when they were formed. Such patterns develop where streamflow tends to be equal in all directions (Morisawa, 1968, p. 163). We conclude that prior to the most recent uplift, the Ozark plateau region was a deeply weathered terrain with little relief which was only slightly higher than the Upper Mississippi Embayment.

The inferred elevation to which the Ozarks was raised is based upon the present elevation of the highest point in the Ozarks and the estimated thickness of rocks that covered that point. Taum Sauk Mountain, the highest point in the St. Francois Mountains, has an elevation of $549 \mathrm{~m}$. In order to calculate uplift from Pleistocene or Pliocene time, the average elevation $(125 \mathrm{~m})$ of the Lafayette Gravel on Crowleys Ridge east of the Salem Plateau is used as a base level. The present relief, therefore, is $424 \mathrm{~m}$. It is known, however, that Pennsylvanian sediments covered all or much of the Ozarks. Sinkholes on the Salem Plateau contain shale and coal of Pennsylvanian age and St. Peter Sandstone of Middle Ordovician age (Harvey, 1980, p. 18). According to McKee (1975) and Wanless (1975), the highest part of the Ozarks was covered with the uppermost units of Pennsylvanian strata whose estimated maximum thickness in the Missouri and Iowa region was $202 \mathrm{~m} \mathrm{(665} \mathrm{ft,} \mathrm{Wanless,}$ 1975). The thickness on the highest part of the Ozarks prior to uplift is of course unknown, but $100 \mathrm{~m}$ is assumed for calculations. Estimates of the thickness of the Paleozoic rocks older than Pennsylvanian that were present 
before uplift are even more uncertain. Paleosinkholes in Cambrian-Ordovician rocks covered by younger carbonate rocks indicate that subaerial erosion occurred long before the present erosion cycle. Two estimates of the total thickness of Paleozoic rocks that may have covered the highest parts of the Ozarks in Pliocene or possibly early Pleistocene time are 300 and $500 \mathrm{~m}$. These estimates are based upon known thicknesses of pre-Pennsylvanian rocks and the assumption that they were thinner on the highest part of the Ozarks. Based upon these estimates of the thickness of rocks that may have covered the highest point in the St. Francois Mountains, which is now $424 \mathrm{~m}$ above the Lafayette Gravel in Crowleys Ridge, the relief in Pliocene or early Pleistocene time is estimated to have been 724 or $924 \mathrm{~m}$. The rates of uplift given in table 3 use the estimated reliefs and the assumption that uplift started in early Pleistocene (1.6 m.y. B.P.), late Pliocene (3.4 m.y. B.P.), or early Pliocene (5.3 m.y. B.P.) (Palmer, 1983).

These rates are long-term average rates, and, except for the two highest ( 453 and $578 \mathrm{~mm}$ ), are very similar to the highest rates estimated by Ahnert (1970, table 2). His highest rates, $114-351 \mathrm{~mm}$ per 1,000 years, are mostly for localities in the Alps of Switzerland and France. His estimated rates are calculated from rates of mean and summit denudations, and he admits that the method used to make the estimates is debatable. The rates are in reasonable agreement, however, with the uplift rates of 0.4-1.1 mm per year given for the European Alps by Clark and Jager (1969). In a study of local relief and maximum height of mountain ranges, Ahnert (1984) concluded that maximum long-term rates of uplift are most probably in the order of $100-1,000 \mathrm{~mm}$ per 1,000 years. He notes that these rates are in the same range of maximum denudation rates in mountainous areas. The estimated rates of the Ozark uplift, therefore, seem reasonable compared with Ahnert's work. These uplift rates are generally lower than those for some parts of the world with high rates of seismicity. Parts of Taiwan, Japan, New Guinea, and the South Island of New Zealand have rates, most of which are associated with active faults, that range from about 1 to $22 \mathrm{~mm}$ per year (Adams, 1980, table 10).

The Ozark rates of uplift can also be compared with rates calculated from relative sea-level changes during the last 500,000 years along the Atlantic coastal plains from Virgina to South Carolina (table 4).

All but one (139) of these rates are much less than the rates estimated for the Ozarks. Both sets of data show rates of uplift are higher for the shortest periods of time over which they were determined. Whether this tendency is the result of some bias in the data, is indicative of more rapid uplift in younger ages, is indicative of a superimposed shorter term cyclicity of uplift, or is the result of other causes is unknown. Certainly all of the above
Table 3. Estimated rates of uplift of the Ozarks based on various estimates of relief and time of uplift

\begin{tabular}{ccc}
\hline $\begin{array}{c}\text { Estimated } \\
\text { relief } \\
\text { (meters) }\end{array}$ & $\begin{array}{c}\text { Time of uplift } \\
\text { (million years } \\
\text { before present) }\end{array}$ & $\begin{array}{c}\text { Rate of uplift } \\
(\mathrm{mm} / 1,000 \mathrm{yrs})\end{array}$ \\
\hline 724 & 1.6 & 453 \\
& 3.4 & 213 \\
924 & 5.3 & 137 \\
& 1.6 & 578 \\
& 3.4 & 272 \\
& 5.3 & 174 \\
\hline
\end{tabular}

Table 4. Rates of uplift along Virginia-South Carolina coast during the last 500,000 years

[From Cronin and others, 1981, p. 237-238]

\begin{tabular}{cccc}
\hline $\begin{array}{c}\text { Years } \\
\text { before } \\
\text { present }\end{array}$ & $\begin{array}{c}\text { Range in } \\
\text { sea levels } \\
\text { relative to } \\
\text { present } \\
\text { sea levels } \\
\text { (in meters) }\end{array}$ & $\begin{array}{c}\text { Range in } \\
\text { uplift rates } \\
(\mathrm{mm} / 1,000 \mathrm{yrs})\end{array}$ & $\begin{array}{c}\text { Average rate } \\
\text { of uplift } \\
(\mathrm{mm} / 1,000 \mathrm{yrs})^{1}\end{array}$ \\
\hline 440,000 & $10-25$ & $23-57$ & 40 \\
188,000 & $2-12$ & $11-64$ & 37 \\
120,000 & $6-9$ & $50-75$ & 63 \\
94,000 & $3-10$ & $32-106$ & 69 \\
72,000 & $4-10$ & $56-139$ & 97 \\
\hline
\end{tabular}

${ }^{1}$ Calculated from the average range of sea levels.

estimated rates of uplift may have large errors, but the differences among them for different regions are so large that they appear to be valid.

Quantitative comparison of rates of uplift of the St. Francois Mountains, which is the structurally highest part of the Ozark dome, with the rates of uplift along the flanks of the dome and other contiguous regions cannot be made with available data. It may seem that the Springfield Plateau west of the study area and the Boston Mountains should have high rates of uplift, because parts of these areas have higher topographic elevations than the Salem Plateau (fig. 12). The St. Francois Mountains have a few peaks, such as Taum Sauk Mountain, as high as the high parts of the Springfield Plateau and Boston Mountains, but the average elevation of the St. Francois Mountains is like that of the Salem Plateau (fig. 12). Consideration of the amounts eroded from these areas, however, indicates that the structurally highest parts of the Ozark dome must have had the highest rates of uplift. The structurally highest parts have had all of the Paleozoic rocks removed (fig. 12), and even most of the Salem Plateau has rocks no younger than Ordovician. In contrast, nearly all of the Springfield Plateau and Boston Mountains are underlain by very resistant Pennsylvanian and Mississippian rocks. As noted earlier in the text, rocks 

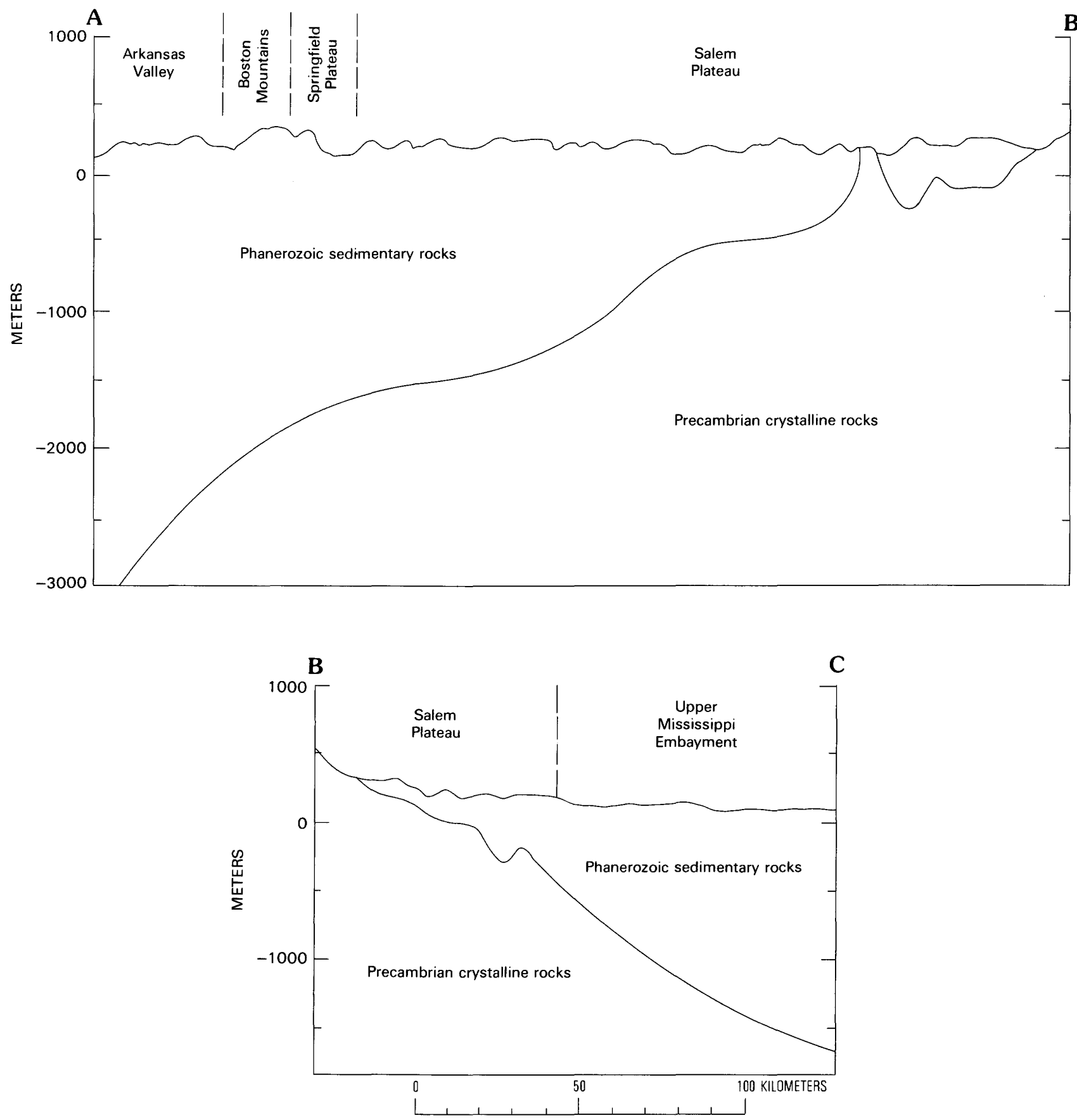

Figure 12. Cross sections showing topography, physiographic section boundaries, and Precambrian surface. Subsurface data from Kisvarsanyi (1975) and Bayley and Muehlberger (1968).

of these ages once covered the Salem Plateau and the St. Francois Mountains also, but they have been removed by erosion. Uplift rates of these areas therefore have been greater than the areas still underlain by the Pennsylvanian and Mississippian rock. One small part of the contiguous Mississippi Embayment is an exception. Russ (1979) concluded that about $10 \mathrm{~m}$ of uplift occurred in the last 6,000 years to form the Lake County uplift (fig. 1) at an average rate of $1,666 \mathrm{~mm}$ per thousand years. The Lake County uplift has the highest rate of seismicity of the embayment. Sandblows associated with the 1811-12 earthquakes are much more abundant south of the uplift (McKeown, 1982), however, which suggests that the largest earthquakes did not occur near the uplift. Whether other parts of the embayment with high seismicity have had uplift or subsidence during the Holocene is not known.

In summary, the above data and arguments for time and rate of uplift of the Ozarks are not definitive but are reasonable. A variety of evidence suggests that major 
uplift started no earlier than early Pliocene and possibly as late as early Pleistocene. The rates of uplift in table 3 could well be minima, because the base level is assumed to be the elevation of the base of the Lafayette Gravel rather than any of the late Pleistocene or Holocene levels of the Mississippi Valley flood plains. The rates of uplift estimated for the Ozarks, however, are certainly higher than those estimated for the U.S. Atlantic coastal plain.

\section{Relationship of Inferred Rates of Uplift to Seismicity}

Nearly all of the seismicity of the study area is in the eastern part of the Salem Plateau section (fig.1) with the exception of the very localized Arkansas earthquake swarm. The authors did not find any geomorphic or geologic features associated with the swarm. They can only speculate that the swarm is related to some local change in effective stress at depth.

The seismicity in the Salem Plateau section is low, but it suggests contemporary tectonic activity. The seismicity cannot be directly related to the inferred longterm uplift rate of the Ozark dome, because both may be episodic and may be in or out of phase with each other. It is reasonable to expect them to be in phase, however, and a closer examination of their possible relationship is warranted.

The rates of seismicity used in the following analysis are from Algermissen and others (1982). To make probability estimates of acceleration and velocity of ground motion generated by earthquakes in the contiguous United States, Algermissen and others (1982) established zones to which maximum magnitudes and number of Modified Mercalli maximum intensity $\mathrm{V}$ earthquakes per year were assigned. The assignments were based upon a combination of instrumental seismicity, historic seismicity, and geologic factors. The rates thus established for each zone (Algermissen and others, 1982, table 1) are probably the best estimates that can be made with current data. As the zones are of different sizes, the rates must be normalized to unit area.

Plate 1 shows the zones with their normalized rate of seismic activity and the physiographic sections of the study area. It is quite apparent that much of the Salem Plateau, which has an estimated uplift rate of 213$272 \mathrm{~mm}$ per 1,000 years, is in or adjacent to zones with the highest rates of seismicity in the region. Data are insufficient to estimate rates of uplift of areas contiguous to the plateau except that, as previously stated, the rates must be lower. It may seem unreasonable for contemporary rates of seismicity to be related to long-term rates of uplift, because study of the longest records of historic seismicity in China indicates that periodicities of damaging seismicity may be hundreds to thousands of years
(McGuire and Barnhard, 1981). However, stationary temporal models of seismicity and a short historical record were judged adequate for calculating the occurrence of felt seismic shaking. McGuire and Barnhard (1981) also noted that the meager evidence available did not suggest any temporal trends in seismicity in the United States at least over the last several centuries. If true, the assumption of a time-stationary model of seismicity is valid.

The sea-level data of Cronin and others (1981), when examined more closely than was done in a previous section and integrated with rates of seismicity, however, suggests that sea levels are related to long-term rates of uplift. Average rates of uplift calculated from the Cronin and others (1981) data for each of their Atlantic Coast localities and grouped according to the seismic zone (Algermissen and others, 1982) in which they are located are given in table 5. Also shown in table 5 are the uplift and seismic-rate data for the Salem Plateau and the Upper Mississippi Embayment. It should be noted that the low rate of seismicity for zone 084 is not representative of the part of the Salem Plateau within the zone. This plateau is only a small part of the total area of the zone which extends about $500 \mathrm{~km}$ northwest of zone 086 (Algermissen and others, 1982, fig. 3).

Inspection of the above data suggests that seismicity rates may correlate with uplift rates. The lowest rate of seismicity for the Atlantic coastal plain (zone 099) has the lowest rate of uplift. The higher rates of seismicity (zones 101 and 102) do not correlate directly with the rates of uplift, but the precision of the data is too low to expect close correlations. The data for the Salem Plateau and Lake County uplift show a distinct association between rates of seismicity and rates of uplift. The Salem Plateau data show lower rates of seismic activity than those for the Atlantic coastal plain even though the uplift rates are higher. The difference in rates for the two regions may indicate that any relationships between uplift rates and seismicity rates are characteristic of a particular tectonic province. Another, perhaps more logical, reason for only qualitative correlation between seismicity rates and uplift rates is that the boundaries of the uplifted areas are not known or ill-defined at best and are not the same as the boundaries of the zones of seismicity which were defined largely by the distribution of seismicity.

The general correlation of rates of seismicity with uplift rates suggests that the boundaries of seismic zones may be constrained or extended if the areal limits of uplift are known and are integrated with the seismic data. For example, the southeast boundary of zone 084 could readily be drawn approximately along the western margin of the Salem Plateau. Even more in accord with the seismicity and uplift data, zones 085, 086, and the Salem Plateau part of zone 084 could be combined into one zone. Uplift or other tectonic deformation, of course, need not be an elastic process that is associated with seisimicity. Aseismic 
Table 5. Rates of uplift and rates of seismicity within seismic zones [Seismicity data from Algermissen and others, 1982]

\begin{tabular}{cccc}
\hline Locality & $\begin{array}{c}\text { Seismic } \\
\text { zone }\end{array}$ & $\begin{array}{c}\text { Rate } \times 10^{7} / \mathrm{A}^{2} \text { normalized } \\
\text { to intensity } V \text { per year }\end{array}$ & $\begin{array}{c}\text { Rate of uplift }{ }^{2} \\
(\mathrm{~mm} / 1,000 \mathrm{yrs})\end{array}$ \\
\end{tabular}

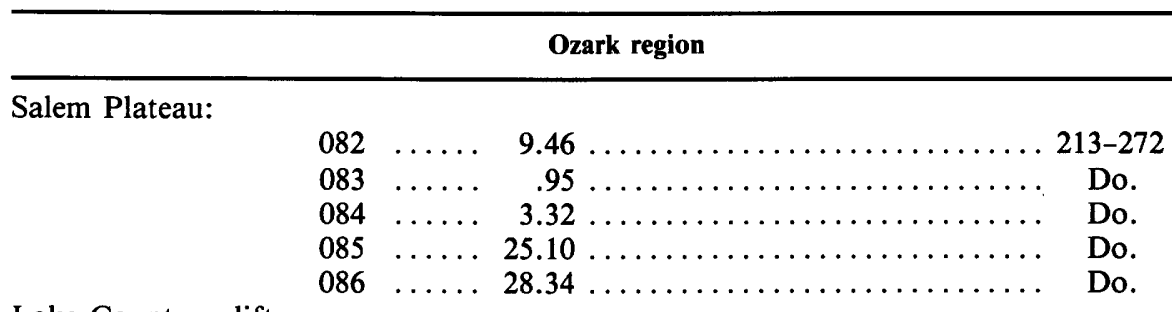

Lake County uplift:

$087 \ldots \ldots 123.36 \ldots \ldots \ldots \ldots \ldots \ldots \ldots \ldots \ldots \ldots \ldots \ldots \ldots$

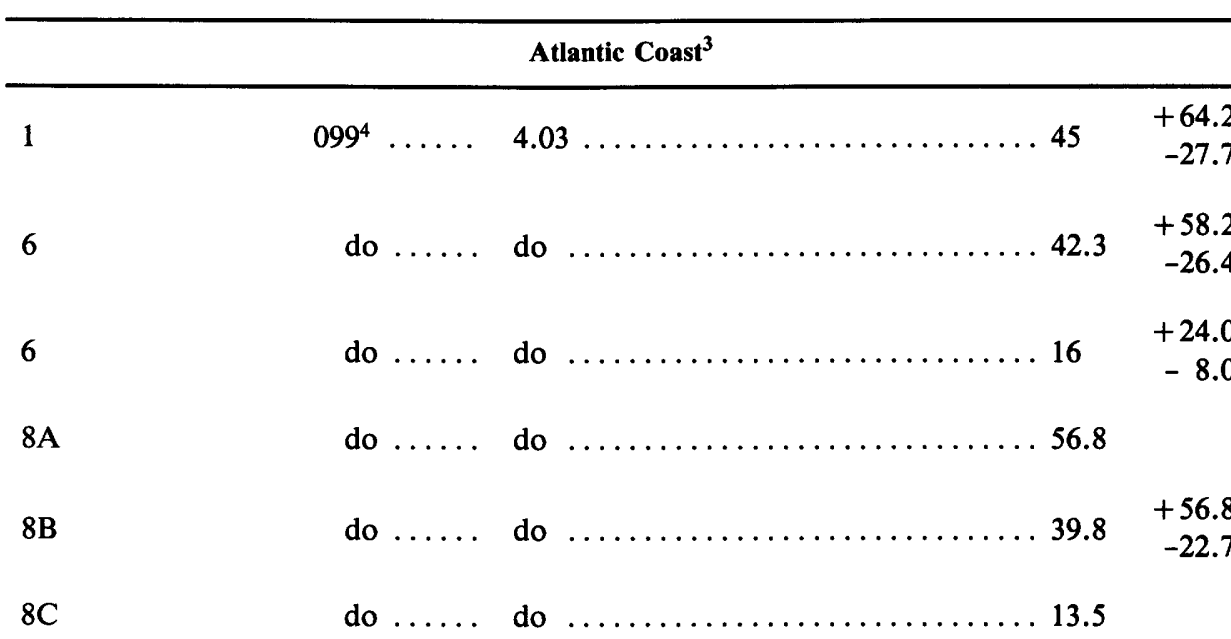

Central Virginia seismic zone:

2

3

4

5
101

do $\ldots \ldots$ do

do ..... do

do

do

$+161.3$ $-64.3$

$+133.3$ $-53.3$

$104.2 \begin{array}{r}+125.0 \\ -83.3\end{array}$

Charleston, South Carolina, seismic zone:

9

102

46.32

$74.4+106.4$

$-42.6$

10

do $\ldots .$. do

$72.9+104.2$

$-41.7$

11

do ..... do

$62.5+75.0$

$-50.0$

12

do ..... d

64.5

$+96.8$

$-32.3$

\footnotetext{
${ }^{1}$ The area-normalized rates were provided by S.L. Hanson (written commun., 1984).

${ }^{2}$ From this report.

${ }^{3}$ Locality numbers are as used by Cronin and others (1981).

${ }^{4}$ Background seismicity.
} 
deformation can occur and therefore not be indicative of possible seismicity.

\section{CONCLUSIONS}

The most important results of this fluvial geomorphic study of the eastern Ozark region are (1) the three physiographic provinces of the study area can be characterized qualitatively and quantitatively by several fluvial geomorphic parameters, (2) several characteristics of the parameters for the Salem Plateau may be interpreted to be the result of geologically young uplift, and (3) this interpretation has important ramifications for delimiting tectonically active provinces and seismic zones.

Inspection of graphic data shows qualitatively that streams on the Salem Plateau section within the study area have less concave stream profiles, relatively high stream-gradient indices over a large area, and more rock available for erosion than the Boston Mountains and Arkansas Valley sections. In addition to these qualitative differences, regression equations of logarithmic values of stream slope and stream length for the Ozark study area and an area in central Pennsylvania show that streams flowing over carbonate rocks of the plateau have statistically unique or different relationships of stream slope to stream length than in the Pennsylvania area. As these qualitative and quantitative differences cannot be accounted for by lithology, streamflow, or structure, recent and possibly continuing uplift of the plateau seems to be the most reasonable explanation. A corollary to this interpretation is that erosion on the Salem Plateau has not kept pace with uplift.

The less concave shape of the stream profiles for the Salem Plateau is especially indicative of inequilibrium. The time needed to attain equilibrium or quasiequilibrium is not known but is likely to be short in geologic spans of time. For example, random walk models of the development of streams suggest that “*** random processes operating in landscape within certain constraints develop rather quickly the characteristics that obtain after a much longer period of time." (Leopold and Langbein, 1962, p. A17). Hack (1960, p. 84) has noted that streams adjust to a quasiequilibrium stage in short periods of geologic time. Thus, identification of regions of erosional inequilibrium using methods such as used in the present study may be useful for inferring recent tectonic activity in areas of several thousand square kilometers regardless of geologic or geomorphic provinces.

Because of a low level of seismicity in the eastern part of the Salem Plateau section and because of the Arkansas earthquake swarm in the Arkansas Valley section, some level of tectonic activity is to be expected. Historic seismic activity within a region may occur only in a zone of brittle fracturing while the rest of the region responds to tectonic activity in other ways, including aseismic ductile deformation. Thus seismicity alone is not adequate to delimit a region of tectonic activity. The quantitative fluvial geomorphic methods employed in the Ozark study along with independent qualitative geologic evidence of tectonic history appear to be a practical system for delimiting regions with levels of tectonic activity too low to produce other more obvious geologic signatures and may be useful to constrain or extend boundaries of seismic zones.

Although delimitation of areas of recent tectonic activity is useful, rates of uplift or subsidence are needed to assess the significance of one area of tectonic activity relative to another. It is possible that the rates may be related to earthquake recurrence intervals. The common practice of estimating recurrence intervals of movement on faults by determining fault offset-time relationships is an analogy of what the rate of regional deformation may indicate for the recurrence rates of earthquakes in a particular region, though aseismic movement may account for some of the tectonic activity.

The regional scale of this semiquantitative geomorphic analysis is apparently not useful for studying smallscale features such as the uplift over the Newport pluton inferrd by Glick (1982). Uplift associated with the pluton may not have been detected because more detailed fluvial gemorphic studies may be required than those made for the Ozark study. Also, the scale of this study apparently is not useful or detecting very recent and very small tectonic deformation such as that associated with the Arkansas earthquake swarm. Any changes in stream gradients in the epicentral area of the swarm would not have been detected because the topography of the Enola quadrangle in which the swarm is located and which was used for this study was mapped in 1960, 22 years before the swarm. Furthermore, no evidence of geomorphic changes was found in limited field observations of the area during 1983, but it is unlikely that geomorphic evidence associated with the Arkansas swarm would be constrained to a time period as short as 23 years. Prior uplift associated with the earthquake swarm would have been detected with this study, however. Russ (1982), for example, concluded that parts of the seismically active Lake County uplift may have started 6,000 years ago; most of it is certainly older than 2,000 years. No apparent regional uplift prior to the 1982 Arkansas earthquake swarm was detected.

\section{ACKNOWLEDGMENTS}

The advice and encouragement of USGS colleagues John T. Hack and David P. Russ are greatly appreciated. Indeed, the work would not have been pursued beyond 
constructing a few stream profiles in the vicinity of the Arkansas earthquake swarm without their insight as to the value of fluvial geomorphology to neotectonics. Boyd R. Haley and Ernest R. Glick, also with the Survey, annotated the geology on all of the profiles. Their contribution of both data and effort is of inestimable value for interpreting the stream-profile data and is very gratefully acknowledged. We are also grateful to Dr. F. E. Cecil of the Colorado School of Mines who provided advice on some of the numerical analyses and contributed substantially to the error analysis. Dr. Sheldon Judson of Princeton University provided valuable comments which are greatly appreciated. We are much indebted to Dr. Larry Mayer of Miami University and to John T. Hack for reviews that helped us to improve both the content and clarity of the report.

\section{REFERENCES}

Adams, John, 1980, Contemporary uplift and erosion of the Southern Alps, New Zealand: Geological Society of America Bulletin, v. 91, 114 p.

Algermissen, S.T., Perkins, D.M., Thenhaus, P.C., Hanson, S.L., and Bender, B.L., 1982, Probabilistic estimates of maximum acceleration and velocity in rock in the contiguous United States: U.S. Geological Survey Open-File Report 82-1033, 99 p., 22 figures, 6 pls., scale 1:7,500,000.

Ahnert, Frank, 1970, Functional relationships between denudation, relief, and uplift in large mid-latitude drainage basins: American Journal of Science, v. 268, no. 3, p. 243-263. 1984, Local relief and the height limits of mountain ranges: American Journal of Science, v. 284, p. 1035-1055.

Baird, D.C., 1962, Experimentation-An introduction to measurement theory and experimental design: Englewood Cliffs, N.J., Prentiss Hall, Inc., 198 p.

Bayley, R.W., and Muehlberger, W.R., Compilers, 1968, Basement rock map of the United States, exclusive of Alaska and Hawaii: U.S. Geological Survey, scale 1:2,500,000, 2 sheets.

Bretz, J.H., 1965, Geomorphic history of the Ozarks of Missouri: Missouri Geological Survey and Water Resources, 2nd Ser., v. $41,147 \mathrm{p}$.

Brush, L.M., Jr., 1961, Drainage basins, channels, and flow characteristics of selected streams in central Pennsylvania: U.S. Geological Survey Professional Paper 282-F, p. 145-181.

Burnett, A.W., and Schumm, S.A., 1983, Alluvial-river response to neotectonic deformation in Louisiana and Mississippi: Science, v. 222, p. 49-50.

Butts, Charles, and Moore, E.S., 1936, Geology and mineral resources of the Bellefonte Quadrangle, Pennsylvania: U.S. Geological Survey Bulletin 855, 111 p.

Caplan, W.M., 1954, Subsurface geology and related oil and gas possibilities of northeastern Arkansas: Arkansas Geological Survey Bulletin 20, 124 p.

Clark, S.P., and Jager, Emilie, 1969, Denudation rate of the Alps from geochronologic and heat flow data: American Journal of Science, v. 267, p. 1143-1160.
Cronin, T.M., Szabo, F.J., Ager, T.A., Hazel, J.E., Owens, J.P., 1981, Quaternary climates and sea levels of the U.S. Atlantic Coastal Plain: Science, v. 211, no. 4479, p. 233-240.

Doering, J.A., 1960, Quaternary surface formations of the southern part of the Atlantic Coastal Plain: Journal of Geology, v. 68, p. 182-202.

Fenneman, N.M., 1938, Physiography of the eastern United States: New York, McGraw Hill Book Company, 714 p.

Flint, R.F., 1941, Ozark segment of Mississippi River: Journal of Geology, v. 49, p. 626-640.

Frezon, S.E., and Glick, E.E., 1959, Pre-Atoka rocks of northern Arkansas: U.S. Geological Survey Professional Paper 314-H, p. 171-189.

Glick, E.E., 1982, Stratigraphy and structure of post-Paleozoic sediments above the Newport pluton of northwestern Arkansas, in McKeown, F.A., and Pakiser, L.C., eds., Investigations of the New Madrid, Missouri, earthquake region: U.S. Geological Survey Professional Paper 1236-K, p. 151-174.

Gustafson, G.C., and Loon, J.C., 1982, Contour accuracy and the national map accuracy standards-a research paper: Surveying and Mapping, v. 42, no. 4, p. 385-402.

Hack, J.T., 1957, Studies of longitudinal stream profiles in Virginia and Maryland: U.S. Geological Survey Professional Paper 294-B, p. 45-97.

1960 , Interpretation of erosional topography in humid temperate regions: American Journal of Science, v. 258A, p. 80-97.

1973a, Stream-profile analysis and stream-gradient index: U.S. Geological Survey Journal of Research, v. 1, no. 4 , p. 421-429.

1973b, Drainage adjustment in the Appalachians, in Morisawa, Marie, ed., Fluvial geomorphology: Binghamton, N.Y., State University of New York, Publications in Geomorphology, p. 51-69.

1982, Physiographic divisions and differential uplift in the Piedmont and Blue Ridge: U.S. Geological Survey Professional Paper 1265, 49 p.

Haley, B.R., Glick, E.E., Bush, W.V., Clardy, B.F., Stone, C.G., Woodward, M.B., and Zachry, D.L., 1976, Geologic map of Arkansas: scale 1:500,000.

Harvey, E.J., 1980, Ground water in the Springfield-Salem Plateaus of southern Missouri and northern Arkansas: U.S. Geological Survey Water-Resources Investigations 80-101, $66 \mathrm{p}$.

Hershey, O.H., 1895, River valleys of the Ozark Plateau: American Geologist, v. 16, p. 338-352.

Holmes, Arthur, 1965, Principles of physical geology: New York, The Ronald Press Company, 1288 p.

Horton, R.E., 1945, Erosional development of streams and their drainage basins-Hydrophysical approach to quantitative morphology: Geological Society of America Bulletin, v. 56, p. 275-370.

Johnston, A.C., 1982, A natural earthquake laboratory in Arkansas: EOS [Transactions of American Geophysical Union], v. 63, no. 50, p. 1209-1210.

Judson, Sheldon, and Ritter, D.F., 1964, Rates of regional denudation in the United States: Journal of Geophysical Research, v. 69, p. 3395-3401. 
Keller, E.A., 1977, Adjustment of drainage to bedrock in regions of contrasting tectonic framework [abs.]: Geological Society of America Abstracts with Programs, v. 9, no. 7, p. 1046.

Keller, E.A., and Rockwell, T.K., 1984, Tectonic geomorphology, Quaternary chronology, and paleoseismicity, in Costa, J.E., and Fleisher, P.J., eds., Developments and applications of geomorphology: New York, Springer-Verlag, p. 203-239.

Kisvarsanyi, E.B., 1975, Data on Precambrian in drillholes of Missouri including rock type and surface configuration: Report of Investigation Number 56, Missouri Department of Natural Resources, 20 p.

Lamb, T.E., Porter, J.E., Lambert, B.F., and Edd, J., 1983, Water resources data, Arkansas, water year 1982: U.S. Geological Survey Water-Data Report AR-82-1, 504 p.; available from U.S. Department of Commerce National Technical Information Service, Springfield, Virginia 22161 as Report USGS/WRD/HD-84/010.

Leopold, L.B., and Langbein, W.B., 1962, The concept of entropy in landscape evolution: U.S. Geological Survey Professional Paper 500-A, 20 p.

Leopold, L.B., Wolman, M.G., and Miller, J.P., 1964, Fluvial processes in geomorphology: San Francisco, W.H. Freeman and Co., 522 p.

Mackin, J.H., 1948, Concept of the graded river: Geological Society of America Bulletin, v. 59, p. 463-511.

Marbut, C.F., 1896, Physical features of Missouri, in Surface features of Missouri: Missouri Geological Survey, v. 10, p. 11-109.

Mayer, Larry, and Wentworth, C.M., 1983, Geomorphic differences east and west of the Stafford fault system, northeastern Virginia [abs.]: Southeastern Section, Geological Society of America, v. 15, no. 2, p. 56.

McGuire, R.K., and Barnhard, T.P., 1981, Effects of temporal variations in seismicity on seismic hazard: Seismological Society of America Bulletin, v. 71, no. 1, p. 231-334.

McKee, E.D., 1975, Interpretation of Pennsylvanian history, in McKee, E.D., and Crosby, E.J., 1975, Paleotectonic investigations of the Pennsylvanian system in the United States: U.S. Geological Survey Professional Paper 853, Part 2, 21 p.

McKeown, F.A., 1982, Overview and discussion, in McKeown F.A., and Pakiser, L.C., eds., Investigation of the New Madrid, Missouri, earthquake region: U.S. Geological Survey Professional Paper 1236-H, p. 1-14.

Morisawa, M.E., 1962, Quantitative geomorphology of some watersheds in the Appalachian Plateau: Geological Society of America Bulletin, v. 73, p. 1025-1046.

1968, Streams, their dynamics and morphology: New York, McGraw-Hill, 175 p.

Mosley, M.P., and Parker, R.S., 1973, Re-evaluation of the relationship of master streams and their drainage basinsdiscussion: Geological Society of America Bulletin, v. 84, p. 3123-3126.

Olive, W.W., 1980, Geologic maps of the Jackson Purchase Region, Kentucky: U.S. Geological Survey Miscellaneous Investigations Map MI-1217, scale 1:500,000.

Palmer, A.R., 1983, Decade of North American Geology 1983 geologic time scale: Geology, v. 11, p. 503-504.

Potter, P.E., 1955, The petrology and origin of the Lafayette gravel-Part 1, Mineralogy and petrology; Part 2, Geomorphic history: Journal of Geology, v. 63 , no. 1, p. 1-38, no. 2, p. 115-132.
Purdue, A.H., 1901, Physiography of the Boston Mountains, Arkansas: Journal of Geology, v. 9, p. 694-701.

Richards, Keith, 1982, Rivers, form and process in alluvial channels: London and New York, Methuen, 357 p.

Russ, D.P., 1979, Late Holocene faulting and earthquake recurrence in the Reelfoot Lake area, northwestern Tennessee: Geological Society of America Bulletin, pt. 1, v. 90, p. 1013-1018.

1982, Style and significance of surface deformation in the vicinity of New Madrid, Missouri, in McKeown, F.A., and Pakiser, L.C., eds., Investigations of the New Madrid, Missouri, earthquake region: U.S. Geological Survey Professional Paper 1236-H, p. 95-114.

Schumm, S.A., 1963a, The disparity between present rates of denudity and orogeny: U.S. Geological Survey Professional Paper 454-H, 13 p.

1963b, Sinuosity of alluvial rivers on the Great Plains: Geological Society of America Bulletin, v. 74, p. 1089-1100. 1977, The fluvial system: New York, Wiley-Interscience, $338 \mathrm{p}$.

Schumm, S.A., Watson, C.C., and Burnett, A.W., 1982, Phase 1, Investigation of Neotectonic activity within the lower Mississippi Valley division: U.S. Army Corps of Engineers, Waterways Experiment Station, Potamology Program (P-1), Report 2, $158 \mathrm{p}$.

Seeber, Leonardo, and Gornitz, V.M., 1983, River profiles along the Himalayan arc as indicators of active tectonics: Tectonophysics, v. 92, p. 335-367.

Shaw, E.W., 1915, Quaternary deformation in southern Illinois and southeastern Missouri [abs.]: Geological Society of America Bulletin, v. 26, no. 1, p. 67.

Shimano, Yasuo, 1975, A study of Hack's law on the relationship between drainage areas and mainstream lengths: Geophysical Review of Japan, v. 48, no. 2, p. 85-97.

Shulits, Samuel, 1941, Rational equation of river-bed profile: Transactions of the American Geophysical Union, v. 41, p. 622-632.

Stearns, R.G., 1967, Warping of the western highland rim peneplain in Tennessee by ground-water sapping: Geological Society of America Bulletin, v. 78, p. 1111-1124.

Strahler, A.N., 1952, Hypsometric (area-altitude) analysis of erosional topography: Geological Society of America Bulletin, v. 63, p. 1117-1142.

Vineyard, J.D., and Feder, G.L., 1974, Springs of Missouri, with a section on Fauna and flora, by W.L. Pflieger and R.G. Lipscomb: Missouri Division of Geology and Land Survey Water Resources Report 29, 267 p.

Waite, L.A., Hatten, D.O., and Cross, P.W., 1983, Water resources data, Missouri, water year 1982: U.S. Geological Survey Water-Data Report MO-82-1, 341 p.; available from U.S. Department of Commerce National Technical Information Service, Springfield, Virginia 22161 as Report USGS/WRD/HD-83/079.

Wanless, H.R., 1975, Missouri and Iowa, in McKee, E.D., and Crosby, E.J., 1975, Paleotectonic investigations of the Pennsylvanian System in the United States: U.S. Geological Survey Professional Paper 853, Part I, Chapter F, p. 97-114.

Webring, Michael, 1981, MINC-A gridding program based on minimum curvature: U.S. Geological Survey Open-File Report 81-1224, 12 p. 
Yeatts, F.R., and Cecil, F.E., 1984, Concepts of physical measurement: Colorado School of Mines Press, 137 p.

Young, Anthony, 1982, Present rate of land erosion: Nature, v. 24, p. 851-852.

Zeuner, F.E., 1959, The Pleistocene Period: London, Hutchinson Scientific and Technical, $447 \mathrm{p}$.

APPENDIX: Description of Computer Programs and of Sources and Magnitudes of Error

\section{Digitizing and Transformation Programs}

A general-purpose digitizing program with special features for maps was used to enter data from $71 \frac{1}{2}$ - and 15-minute quadrangle maps. Points on the map were entered as distances in inches from a selected origin. Elevations were recorded at the point where a stream course crossed a contour line. The $x, y$ data were then transformed into latitude and longitude for a Lambert conic conformal projection. Several utility programs were written to concatenate parts of single streams in adjacent quadrangles to complete each stream.

\section{Map-Plotting Programs}

A program to plot the stream courses at different scales was used to check the digitized data for errors. In addition, numerical values (for example, elevations) could be plotted at various points along the stream courses in order to examine and, when appropriate, to contour these values (see fig. 6).

\section{Profile Programs}

Data for individual streams were plotted in various ways: (1) profiles of elevation versus distance along the stream, (2) consecutive numbers or elevation in feet at each elevation change, and (3) elevation versus the In of the distance along the stream.

\section{Analysis of the Stream Data}

We calculated stream-gradient indices $(S L)$, derivatives of the stream gradient indices $\left(S L^{\prime}\right)$, or second derivative, and a two-dimensional hypsometric value for each stream.

The gradient index $(S L)$ is essentially the slope (first derivative) of the semilog plot of the stream profile and is calculated from

$$
S L_{n}=\frac{h_{n+1}-h_{n+2}}{\ln \left(L_{n+2}\right)-\ln \left(L_{n+1}\right)},
$$

where $h_{n+1}$ and $h_{n+2}$ are elevations at two consecutive contours crossed by a stream and $L_{n+1}$ and $L_{n+2}$ are the distances from the stream headwaters to the elevation crossings. The distances were calculated using the Pythagorean Theorem between every adjacent latitude/ longitude pair and summed over the entire distance (see fig. 13). The $S L$ value for the first elevation change cannot be calculated because one cannot take the log of zero. For plotting purposes, the $S L$ values were associated with the average value of the latitude and longitude pairs at the contour crossing.

The second derivative of any curve gives a quantitative assessment of the inflections on a curve. Likewise, our second derivative calculations were an attempt to locate large inflections on the semilog plots. As is discussed in the error analysis later, many of these inflections may only be due to map inaccuracies. We plotted the absolute value of the second derivative but discovered that these values were not readily contoured, probably because they were so sensitive to error. The second derivative, $S L^{\prime}$, is defined as

$$
S L_{n}{ }^{\prime}=\frac{S L_{n}-S L_{n+1}}{\ln \left[\left(L_{n+3}-L_{n+2}\right) / 2\right]-\ln \left[\left(L_{n+2}-L_{n+1}\right) / 2\right]} .
$$

Note that the initial second derivative value that may be calculated, $S L_{1}{ }^{\prime}$, required the second, third, and fourth elevations and their respective stream distance and $S L$ values (see fig. 13).

The two-dimensional hypsometric value was determined by calculating the area of horizontal slices under the stream profile between adjacent elevation changes. The area of each slice $(a)$ was

$$
a=\left(h_{n}-h_{n+1}\right) \cdot\left[L_{n}+\left(L_{n+1}-L_{n}\right) / 2\right],
$$

so that half of the rectangle with corners located at Cartesian coordinates $\left(h_{n}, L_{n}\right),\left(h_{n}, L_{n+1}\right),\left(h_{n+1}, L_{n}\right),\left(h_{n+1}\right.$, $L_{n+1}$ ) was added to the rectangle with corners located at Cartesian coordinates $\left(h_{n}, 0\right),\left(h_{n}, L_{n}\right),\left(h_{n+1}, 0\right),\left(h_{n+1}\right.$, $L_{n}$ ). These $a_{n}$ 's were summed over all $n$ 's to estimate the area under the profile curve between the headwaters and the mouth of the stream. This sum was divided by the rectangular area defined by the highest and lowest elevations of the stream and the intervening length to give the percentage of area remaining to be eroded assuming an original flat surface. An option for defining the elevations to be used in all the calculations allows the operator to essentially skip certain elevation points. Therefore, even though some quadrangle maps had 5 -ft contour intervals or 20 -ft contour intervals, a constant elevation 


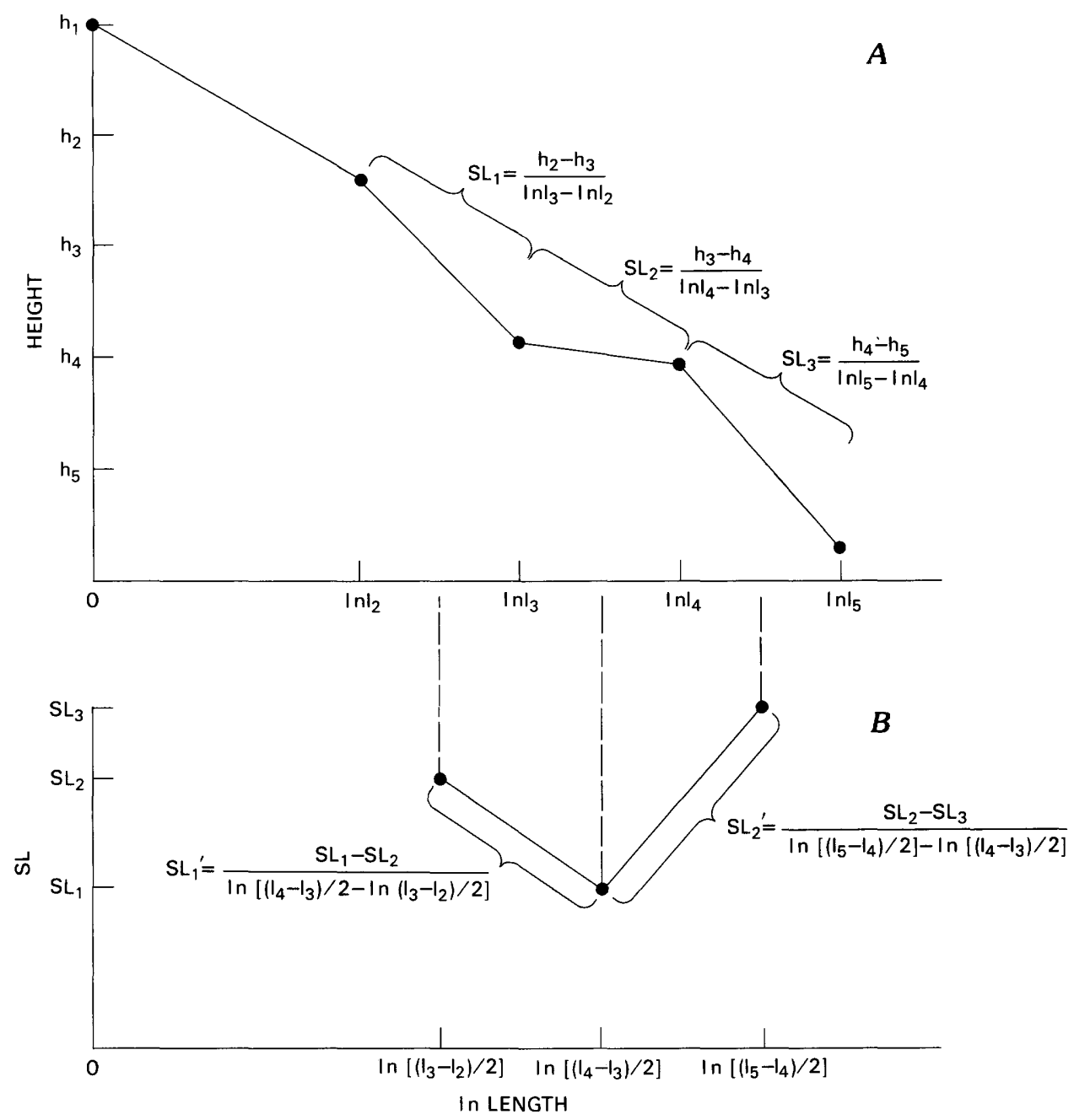

Figure 13. Illustration of the calculation of the $S L$ and $S L^{\prime}$ values. In $A, S L_{1}, S L_{2}$, and $S L_{3}$ are the slopes of the semilog plot between the second, third, fourth, and fifth (elevation, In length) coordinate pairs. In $B, S L_{1}^{\prime}$ and $S L_{2}{ }^{\prime}$ are the slopes of the semilog plot of $S L$ versus In length.

difference could be used. Thus, the area under the curve could be calculated at 20 - $\mathrm{ft}$ intervals. Initially we hoped this option would allow comparison at $20-\mathrm{ft}$ intervals among streams. We later realized this would not be a valid comparison, however, because there would be no normalization for length. Subsequently, only the whole-stream two-dimensional hypsometric value was used.

The slope, $S_{n}$, of each stream was calculated using

$$
S_{n}=\frac{h_{n}-h_{n+1}}{l_{n+1}-l_{n}}
$$

in order to compare this study with other studies that only used a slope rather than Hack's gradient index.

\section{Graytone Plots}

In order to produce a smoothed, machine contoured map to compare with the subenvelope map (fig. 5) and the whole stream $S L$ map (fig. 8) two other sets of programs were used. Our $S L$ and elevation data were gridded by using a minimum curvature program, MINC (Webring, 1981), and a 30 by 40 grid. The gridded data were then transformed into a graytone plot using the $\mathrm{Na}$ tional Center for Atmospheric Research's 1972 graphics program, HAFTON. Converting the grid to a graytone plot introduced some additional smoothing.

\section{Error Analysis}

Calculations of stream-gradient indices and stream slopes have four sources of error which can be readily 
estimated: (1) map projection error, (2) operator error during digitization, (3) smoothing error during digitization, and (4) elevation error. The elevation error is by far the greatest. In addition to these four estimatable errors, two other errors exist that could not be estimated. True stream lengths are systematically decreased when mapped at a scale of 1:24,000. In addition, any error introduced by warping, stretching, or shrinking of the paper quadrangle maps during digitizing could not be estimated. The first systematic error in stream length will not affect comparison of different stream parameters within this study, though it might be more significant when trying to compare parameters between field-determined stream parameters and this study. The second error will be much smaller than elevation errors and is therefore insignificant.

The error associated with differences in the map projection of the topographic maps and the projection we used for transforming the digitized data from inches to latitude and longitude data was negligible. Most of the quadrangle maps were made with a polyconic projection. A few used a transverse Mercator projection. We used a Lambert conic conformal projection for transformation. To estimate the error between the polyconic projection and the Lambert conic conformal projection, the $21 / 2$-minute grid marks on a $71 / 2$-minute quadrangle were digitized. The difference between the two projections was calculated using $110,934 \mathrm{~m}$ per degree of latitude and $91,428 \mathrm{~m}$ per degree of longitude and the Pythagorean Theorem to determine the distance in meters between the original point and the digitized point. The average difference over 16 grid points was $32.8 \mathrm{~m}$ or 0.3 percent difference in location of the most distant point from the origin. Though the error for the difference between a transverse Mercator projection and the Lambert conic conformal projection was not estimated, it can be assumed to be of the same order. This error is insignificant in light of the three other errors and will be ignored hereafter.

The operator error during digitization was roughly estimated by comparing the total length of two different streams, each digitized by two different operators using high-frequency digitization (see section on smoothing error for discussion of digitization frequencies). Because a higher frequency was used to test for operator error than the frequency used to digitized streams for the Ozark study, the error estimated from this test would be larger than that for the study. Averaging the total stream length for the two streams showed a 2.4 percent difference between the two operators, for a mean error of 1.2 percent. Though no true distribution of errors exists for a sample of two operators, this 1.2 percent mean error will be taken as a rough approximation for a standard error, $\Delta L$.

The smoothing of a stream course during digitization can be controlled to some extent. The Summagraphics ${ }^{1}$ digitizer can be adjusted to digitize over a range of sampling frequencies. More data points are entered at high frequency than at low frequency, though points will not be entered at a sampling interval of less than 0.005 inches. Consequently, at low frequency, a greater amount of smoothing will occur. Speed and accuracy must be balanced against the size of resulting data. Computer processing of streams digitized at high frequency was much slower and resulted in much larger data files. For example, the upper quarter of the Black River was digitized at high speed, and contained 7,913 $(x, y)$ points. The lower three-fourths, digitized at low frequency, contained only 1,349 points. Due to the difficulties associated with storing and using the high-frequency data sets, the 71 streams were consequently digitized at low frequency. To assess the resulting error, we compared two streams each digitized at both high and low frequencies. One stream (Sullivan Creek) had many meanders and the other (Clear Creek) had fewer meanders. The average difference in length between the low-frequency digitized data and the high-frequency digitized data was 9.0 percent, (Sullivan Creek averaged 8.1 percent and Clear Creek averaged 9.9 percent). This implies that though greater smoothing occurred using low-frequency rather than high-frequency digitization, there appears to be no greater smoothing of the more sinuous stream. It should be noted that the smoothing error is a systematic error; that is, all stream gradients and stream-gradient indices will be slightly higher when calculated from the low-frequency data than they would have been if calculated from the high-frequency data. Because this is a nonrandom error, it cannot be numerically combined with the other estimated errors. For comparison of slope and stream gradient indices within a single study, this systematic error is not important. It does, however, become more significant when comparing the results of our study with the results of other studies where length was determined in a different manner.

Estimating the error associated with location of the contours used to determine elevations is more difficult. Seven and one-half minute quadrangle maps conforming to commonly accepted national map accuracy standards meet a vertical accuracy standard as follows:

The elevation of 90 percent of all points tested should be correct within half of the contour interval. On a map with a contour interval of $10 \mathrm{ft}$, therefore, the map will correctly place 90 percent of all points tested within $5 \mathrm{ft}$ $(1.5 \mathrm{~m})$ of the actual elevation.

Thus, assuming a normal distribution, each elevation taken off the map has a \pm 3 -ft error associated with it when the contour interval is $10 \mathrm{ft}$ and the error is assumed to be $\pm 1 \sigma$. Most contour intervals in this study were 20 $\mathrm{ft}$. Therefore the standard error is $\pm 6 \mathrm{ft}$ or 30 percent. 
There are two calculated sources of random error-elevation error of 30 percent for each elevation and an operator error in each length calculation of 1.2 percent. When calculating $S$ or $S L$, progressive lengths along an individual stream are used. Consequently, the error associated with the shorter length, $L_{1}$, is contained entirely within the error associated with the longer length, $L_{2}$. The error in length, $\Delta L$ is therefore simply 1.2 percent. When examining differences in elevation, we assumed that the error between adjacent contours are independent, even though this is certainly the worst possible case. There have been no tests of relative error on the $71 / 2$-minute quadrangle maps meeting the national mapping standards (Shirley Sheldrake, oral commun., 1985). If the error for $h_{1}$ is $\Delta h_{1}$ and the error for $h_{2}$ is $\Delta h_{2}$, then the error $\Delta h$, for $h_{1}-h_{2}$, is obtained by combining the individual independent errors in quadrature (Baird, 1962, p. 63; Yeatts and Cecil, 1984, p. 19). Thus,

$$
\Delta h=\left(\Delta h_{1}^{2}+\Delta h_{2}^{2}\right)^{0.5} .
$$

If the contour interval, $h$, is $20 \mathrm{ft}$, then $\Delta h_{1}=\Delta h_{2}=6$ $\mathrm{ft}, \Delta h$ is $8.5 \mathrm{ft}$ and $\frac{\Delta h}{h}$ is 0.43 .

To find the error in an $S L$ or slope calculation, the height and length errors should, in principle, be combined. However, because the error in length, $\Delta L$, is so small ( 0.01 or 1 percent) and is an order of magnitude less than the error in height, $\Delta L$ ( 0.43 or 43 percent), the combined error is virtually identical to $\Delta h$, or 43 percent.

Our estimated error, however, is probably more than actually occurs. If the error in adjacent contour lines has a systematic component, the error would be less. The best illustrations of noise or error in our data are the $S L$ versus-length plots. As shown above, the standard error for $S$ and $S L$ calculations is 43 percent. In other words, 68 percent of all $S L$ and $S$ values should lie within 43 percent of their actual value. In order to compare this with the observed error, some assumptions have to be made. As shown on figure 14, the maximum number of erroneous slope calculations contributing to a spike is two, assuming that the real slope is constant. Under special circumstances, for example, if the slope increases after two erroneous points, a spike might be a combination of error and real values. However, for the most part, single-point and double-point spikes can be assumed to be erroneous without field checking.

A moving-average scheme of $S L$ values versus length was used to calculate how closely a single point approximated its "actual" value. Because two adjacent points in a single spike may be due to error, more than two adjacent points had to be used to determine the "actual" value. Thus, one of our assumptions is that an average of four or five adjacent points represents the "actual" value. We determined the average in two ways. The first average, avg(1), was calculated under the assumption that the single point, $S L_{i}$, under examination was anomalous and should not be included in the average:

$$
\operatorname{avg}(1)=\left(S L_{i-2}+S L_{i-1}+S L_{i+1}+S L_{i+2}\right) / 4 .
$$

The second average, avg(2), was calculated under the assumption that the single $S L$ point was not anomalous:

$$
\operatorname{avg}(2)=\left(S L_{i-2}+S L_{i-1}+S L_{i}+S L_{i+1}+S L_{i+2}\right) / 5 \text {. }
$$

A percent error, $e_{i}$, for each $S L_{i}$ is then

$$
\mathrm{e}_{\mathrm{i}}=\left(S L_{i} \cdot \mathrm{ave}\right) / \mathrm{ave},
$$

where ave can be either avg(1) or $\operatorname{avg}(2)$.

Standard error, $s$, is usually determined by

$$
s=\left[\sum_{i=1}^{n}\left(x_{i}-\bar{x}\right) /(n-1)\right]^{0.5},
$$

where $x_{i}$ is an individual value, $\bar{x}$ is the mean of all $x_{i}^{\prime}$ 's, and $n$ is the total number of data values. Because the original error associated with the contour lines is expressed as a percentage error, we have modified the usual calculation of the standard error to be a calculation involving percent errors:

$$
\sigma=\left[\sum_{i=1}^{n} e_{i}^{2} /(n-1)\right]^{0.5},
$$

where $\sigma$ is the percent standard error, $e_{i}$ is the percent error determined above, and $n$ is the number of single $S L_{i}$ or slope values being examined.

The distribution of the $\sigma$ values for 66 streams (Black Fork was not included because it contained too few $S L$ values) was very right-skewed. The median value is therefore the best measure of central tendency. The median when using avg(1) was 0.35 or a 35 -percent standard error, and the median $\sigma$ value when using avg(2) was 0.27 or a 27 -percent standard error. Both schemes produce empirical errors less than the 43 percent estimated error above.

The observed 35- to 27-percent standard error values are in closer agreement with actual errors in elevation determined for a data set of USGS test elevations on maps produced between 1972 and 1977 (Gustafson and Loon, 1982). Gustafson and Loon took 343 USGS test elevation points distributed over various terrains (including twelve test points in Arkansas and Missouri) and determined the actual root mean square (rms) error or standard error for the mapped points. One hundred and twenty-three of these points from maps with a $20-\mathrm{ft}$ contour interval had a standard error of $\pm 3.98 \mathrm{ft}$ as opposed 
A

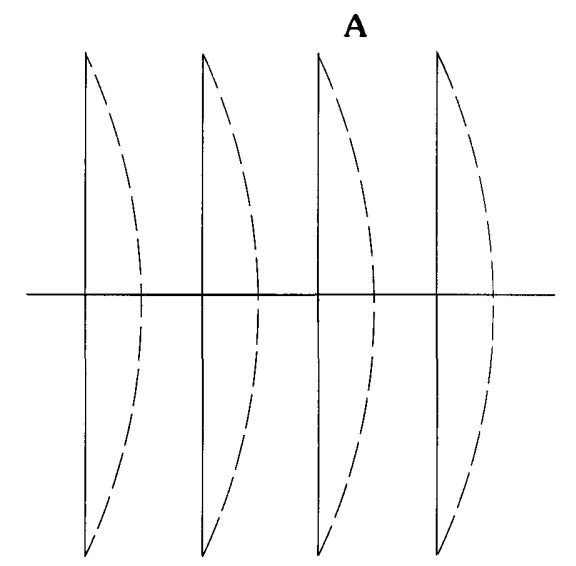

峛

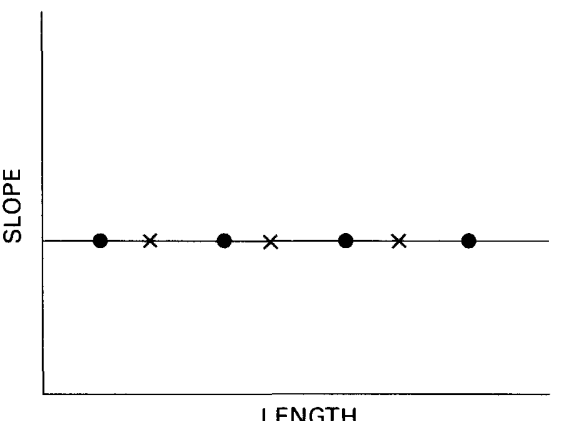

B
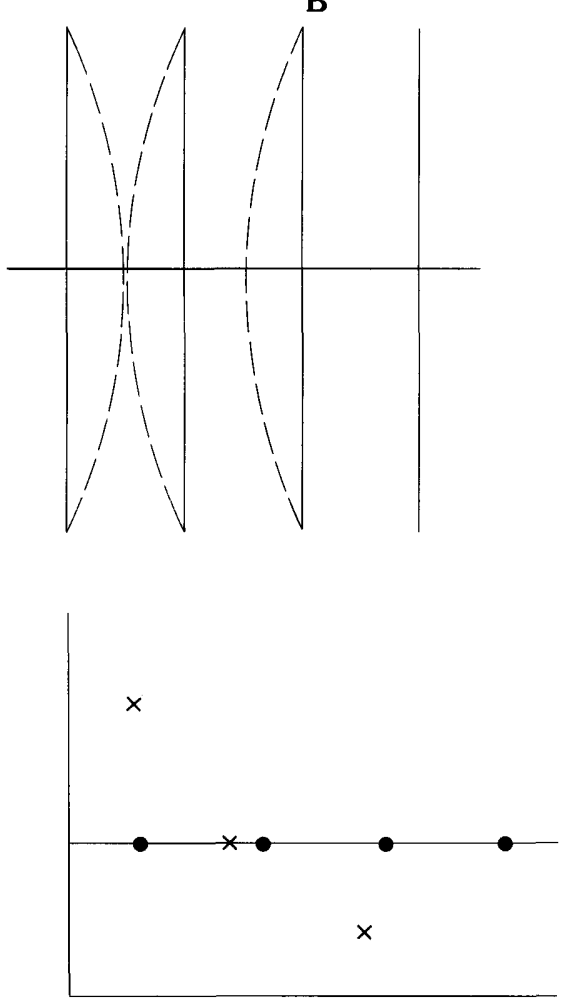

LENGTH
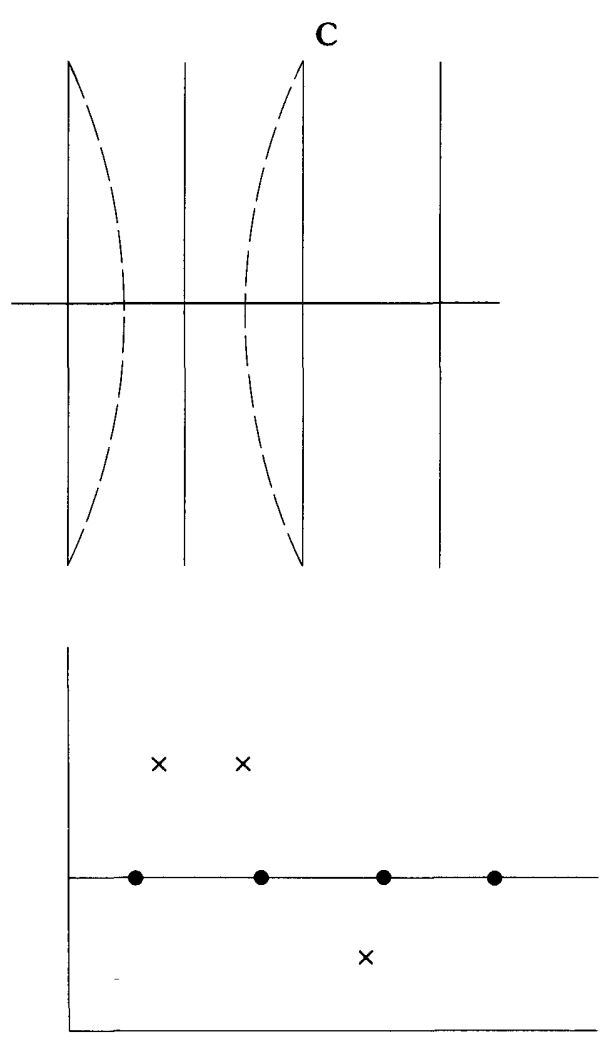

LENGTH

\section{EXPLANATION}

- Slope calculated from correctly located contours

$\times \quad$ Slope calculated from incorrectly located contours

Stream course

Figure 14. Three cases possible if the actual stream slope is assumed to be constant and the standard error of each 20 - $\mathrm{ft}$ contour is $\pm 6 \mathrm{ft}$. Solid line represents correct location of contours; short-dashed line represents possible incorrect location of contours as they may actually occur on maps. Systematically mislocated contours in $(A)$ result in incorrect length along a stream. $(B)$ and $(C)$ illustrate the "spikes" that can be produced by mislocated contours in plots of slope versus length. $(C)$ illustrates the maximum number of points possible in a "spike" due to error. 
to the maximum standard error of $\pm 6 \mathrm{ft}$ required by national mapping standards. Gustafson and Loon's (1982) observed error was therefore 20 percent. This would give a $\Delta h / h$ of 28 percent.

Error analysis of our study brings out two important points. Individual variations in $S L$ or $S$ must be considered suspect until verified by field checking. There is a standard error for $S L$ and $S$ values in the range of 43 to 27 percent, the latter being the more realistic error estimate. Both our error analysis and that of Gustafson and Loon (1982) point out that the errors associated with the elevations on the maps we have used are probably less than the plus or minus one-half contour-interval error (at a 90-percent confidence level) determined for absolute elevations by national mapping standards. Though individual variations in $S L$ and $S$ values must be used with great care, trends in $S L$ or $S$ values can still be valid and used for regional analysis. 
